Article

\title{
Thallium(I) Tropolonates: Synthesis, Structure, Spectral Characteristics, and Antimicrobial Activity Compared to Lead(II) and Bismuth(III) Analogues
}

\author{
Krzysztof Lyczko ${ }^{1, *(D)}$, Monika Lyczko ${ }^{1}$, Marzena Banasiewicz ${ }^{2}$, Karolina Wegrzynska ${ }^{3}$, Anna Ziółko ${ }^{3}$, \\ Anna Baraniak $^{3}$ (D) and Jan Cz. Dobrowolski 1,3 \\ 1 Institute of Nuclear Chemistry and Technology, Dorodna 16, 03-195 Warsaw, Poland; \\ m.lyczko@ichtj.waw.pl (M.L.); j.dobrowolski@nil.gov.pl (J.C.D.) \\ 2 Institute of Physics PAS, Al. Lotnikow 32/46, 02-668 Warsaw, Poland; mbanas@ifpan.edu.pl \\ 3 National Medicines Institute, Chełmska 30/34, 00-725 Warsaw, Poland; k.wegrzynska@nil.gov.pl (K.W.); \\ a.ziolko@nil.gov.pl (A.Z.); a.baraniak@nil.gov.pl (A.B.) \\ * Correspondence: k.lyczko@ichtj.waw.pl
}

Citation: Lyczko, K.; Lyczko, M.; Banasiewicz, M.; Wegrzynska, K.;

Ziółko, A.; Baraniak, A.;

Dobrowolski, J.C. Thallium(I) Tropolonates: Synthesis, Structure, Spectral Characteristics, and Antimicrobial Activity Compared to Lead(II) and Bismuth(III) Analogues. Molecules 2022, 27, 183. https:// doi.org/10.3390/molecules27010183

Academic Editors: Artem

L. Gushchin and Sergey A. Adonin

Received: 8 December 2021

Accepted: 27 December 2021

Published: 29 December 2021

Publisher's Note: MDPI stays neutral with regard to jurisdictional claims in published maps and institutional affiliations.

Copyright: (C) 2021 by the authors. Licensee MDPI, Basel, Switzerland. This article is an open access article distributed under the terms and conditions of the Creative Commons Attribution (CC BY) license (https:// creativecommons.org/licenses/by/ $4.0 /)$.

\begin{abstract}
Synthesis, single-crystal X-ray determination diffraction and FT-IR, NMR $\left({ }^{1} \mathrm{H},{ }^{13} \mathrm{C}\right.$, ${ }^{19} \mathrm{~F}$ and $\left.{ }^{205} \mathrm{Tl}\right), \mathrm{UV}-\mathrm{vis}$, and luminescence spectra characteristics were described for series of thallium(I) compounds: thallium(I) triflate (Tl(OTf)), 1:1 co-crystals of thallium(I) triflate and tropolone (Htrop), Tl(OTf)·Htrop, as well as simple thallium(I) chelates: Tl(trop) (1), Tl(5-metrop) (2), Tl(hino) (3), with Htrop, 5-methyltropolone (5-meHtrop), 4-isopropyltropolone (hinokitiol, Hhino), respectively, and additionally more complex $\left\{\mathrm{Tl} @[\mathrm{Tl}(\mathrm{hino})]_{6}\right\}$ (OTf) (4) compound. Comparison of their antimicrobial activity with selected lead(II) and bismuth(III) analogs and free ligands showed that only bismuth(III) complexes demonstrated significant antimicrobial activity, from two- to fivefold larger than the free ligands.
\end{abstract}

Keywords: thallium(I) triflate; thallium(I) complexes; tropolone; 5-methyltropolone; hinokitiol; crystal structure; antimicrobial activity

\section{Introduction}

Tropolone (2-hydroxy-2,4,6-cycloheptatriene-1-one, Htrop) and its derivatives contain the aromatic seven-membered ring with the neighboring carbonyl and hydroxyl groups. They exhibit interesting physicochemical properties, as well as antitumor, insecticidal, fungicidal, antimicrobial, and neuroprotective activity [1-6]. Moreover, they are also suitable chelators for various metal ions $[7,8]$. Due to their broad and potent antimicrobial activity, some naturally occurring tropolones are components of the formulations for cosmetics and dentistry $[9,10]$.

The first tropolonato complexes with the $p$-block, period-6, metal ions, such as [Bi ${ }^{\mathrm{III}}$ (trop) ${ }_{2} \mathrm{Cl}$ ], $\left.\mathrm{Na}\left[\mathrm{Bi}^{\mathrm{III}} \text { (trop) }\right)_{4}\right], \mathrm{Bi}^{\mathrm{III}}$ (trop) $)_{3}, \mathrm{~Pb}^{\mathrm{II}}$ (trop) $)_{2}$, and $\mathrm{Pb}^{\mathrm{IV}}$ (trop) $)_{4}$, were synthesized more than half a century ago [11,12]. In the 1990s, a new series of bismuth(III) complexes with tropolones was synthesized; however, the structures of only two of them, aquabis(4,5-benzotropolonato)bismuth(III) nitrate and nitratobis(tropolonato)bismuth(III), were determined [13]. Over a decade ago, we demonstrated that formation of different polymeric or dimeric lead(II) tropolonates $\left(\left[\mathrm{Pb}_{3}(\operatorname{trop})_{4}\left(\mathrm{ClO}_{4}\right)_{2}\right]_{\mathrm{n}},\left[\mathrm{Pb}_{2}(\operatorname{trop})_{2}\left(\mathrm{NO}_{3}\right)_{2} \mathrm{MeOH}\right]_{\mathrm{n}}\right.$, $\left[\mathrm{Pb} \text { (trop) }\left(\mathrm{CF}_{3} \mathrm{SO}_{3}\right)\left(\mathrm{H}_{2} \mathrm{O}\right)\right]_{\mathrm{n}}$, and $\left.[\mathrm{Pb} \text { (trop })_{2}\right]_{2}$ ) depended on $\mathrm{pH}$ and counterion presence [14]. A few years ago, we also performed a similar study on bismuth(III) tropolonates and 5-methyltropolonates (5-meHtrop): ([ $\left[\mathrm{Bi}_{2}(\text { trop })_{4}\left(\mathrm{ClO}_{4}\right)_{2}\right]_{\mathrm{n}},\left[\mathrm{Bi}_{2}(\text { trop })_{4}\left(\mathrm{NO}_{3}\right)_{2}\right]_{\mathrm{n}},\left[\mathrm{Bi}(\operatorname{trop})_{2}\right.$ $\left.\left(\mathrm{CF}_{3} \mathrm{SO}_{3}\right)\right]_{2},\left\{\left[\mathrm{Bi}_{2}(5 \text {-metrop })_{4}\left(\mathrm{ClO}_{4}\right) \mathrm{MeOH}\right] \mathrm{ClO}_{4}\right\}_{n}, \mathrm{Bi}(5 \text {-metrop })_{2}\left(\mathrm{NO}_{3}\right)$ and $\left[\mathrm{Bi}_{2} \text { (5-metrop }\right)_{4}$ $\left.\left.\left(\mathrm{CF}_{3} \mathrm{SO}_{3}\right)_{2}\right]_{n}\right)[15]$. Recently, we revealed that in the $[\mathrm{Pb} \text { (trop })_{2}$ (Htrop)] and [Bi(trop $)_{2}$ (Htrop) $\left(\mathrm{CF}_{3} \mathrm{SO}_{3}\right)$ ] structures, the tropolone ligands act as both a neutral monodentate ligand (Htrop) 
and a bidentate chelating anion (trop ${ }^{-}$) [16]. For 4-isopropyltropolone (hinokitiol, Hhino) the simple $\left[\mathrm{Pb}(\mathrm{hino})_{2}\right]_{\mathrm{n}}$ and $\mathrm{Bi}(\mathrm{hino})_{3} \mathrm{EtOH}$ complexes have only been presented $[7,17]$.

Despite many studies on the heaviest $p$-block metal tropolonates, no thallium(I) analogues have been presented until now, except structural characterization of two, the $\mathrm{Tl}^{\mathrm{III}}$ (trop) $\mathrm{Me}_{2}$ and $\mathrm{Tl}^{\mathrm{III}}$ (trop) $\mathrm{Ph}_{2}$ complexes $[18,19]$.

A rich structural variety of thallium(I) compounds [20-28] makes them interesting for structural and materials research. The diversity stems from the possibility of the $\mathrm{Tl}^{+}$ ion to adopt a wide range of coordination numbers, and the presence of $6 s^{2}$ electrons enabling participation in $\mathrm{Tl} \cdots \mathrm{X}(\mathrm{X}-\mathrm{Tl}, \mathrm{C}, \mathrm{H}$ or halogen atoms) secondary interactions. In addition, attention recently has been focused on thallium(I) compounds bearing metallophilic interactions with other metal centers [29-32]. Still, unlike most $p$-block metals, the thallium compounds are infrequently studied due to their high toxicity. Taking all the above into account and being inspired by earlier works on lead(II) and bismuth(III) tropolonates, here, we characterized structures of new thallium(I) compounds with unsubstituted tropolone, 5-methyltropolone, and hinokitiol. Moreover, after sustained efforts, we obtained thallium(I) triflate single crystals appropriate for the X-ray determination. Eventually, we examined the in vitro antimicrobial activity of new thallium(I) complexes and free tropolone ligands, and compared it with those of similar lead(II) and bismuth(III) complexes we studied previously $[14,15,17]$. Various metal complexes are still interesting due to their potential antibacterial properties [33-36].

\section{Results and Discussion}

\subsection{Synthesis}

The thallium(I) tropolonate complexes cannot be obtained by simple mixing of thallium(I) nitrate $(\mathrm{V})$ or triflate with a tropolone ligand. An attempt of such a direct synthesis ends with 1:1 (Tl(OTf).Htrop) co-crystals. Moreover, similar adducts with the other tropolone derivatives are not formed. Simple thallium(I) complexes with tropolone (1) and 5-methyltropolone (2) can be synthesized by adding equimolar amounts of ammonia to the mixture of thallium(I) nitrate(V) or triflate salt and the respective tropolone derivative. A simple Tl(hino) complex (3) is formed only when using thallium(I) nitrate(V), while in the case of the triflate salt, the more complex compound $\left\{\mathrm{Tl} @[\mathrm{Tl}(\text { hino })]_{6}\right\}(\mathrm{OTf})(4)$ is obtained.

\subsection{Crystal Structures}

Crystal structures of all the thallium(I) compounds were determined at low temperature using a single-crystal X-ray diffraction method (Supplementary Materials Figure S1).

\subsubsection{Crystal Structures of Thallium(I) Triflate and Its Adduct with Tropolone}

Despite that the thallium(I) triflate (Tl(OTf)) was mainly amorphous, it was possible to obtain some crystalline material suitable enough for scXRD measurements. As a result, it was found that two crystallographically independent thallium(I) ions were present in the crystal structure of $\mathrm{Tl}(\mathrm{OTf})$ (Figure 1). Both of them were surrounded by six oxygen atoms from five neighboring triflate ions, with an average $\mathrm{Tl} \cdots \mathrm{O}$ distance of $2.88(2) \AA$ for Tl1 (range 2.72(2)-3.09(2)) and 2.89(2) $\AA$ for T12 (range 2.78(2)-3.06(2)). In addition, two $\mathrm{Tl} \cdots \mathrm{F}$ contacts from two additional triflate ions in the range of 3.22(1)-3.43(1) $\AA$, which were close to the sum of the van der Waals radii of $\mathrm{Tl}$ and $\mathrm{F}$ atoms $(3.43 \AA$ ), were found for both metal ions [37]. All these $\mathrm{Tl} \cdots \mathrm{O}$ and $\mathrm{Tl} \cdots \mathrm{F}$ distances are shown in Table 1. The

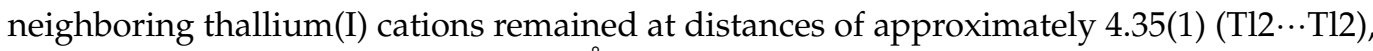

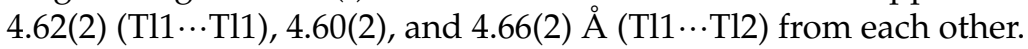




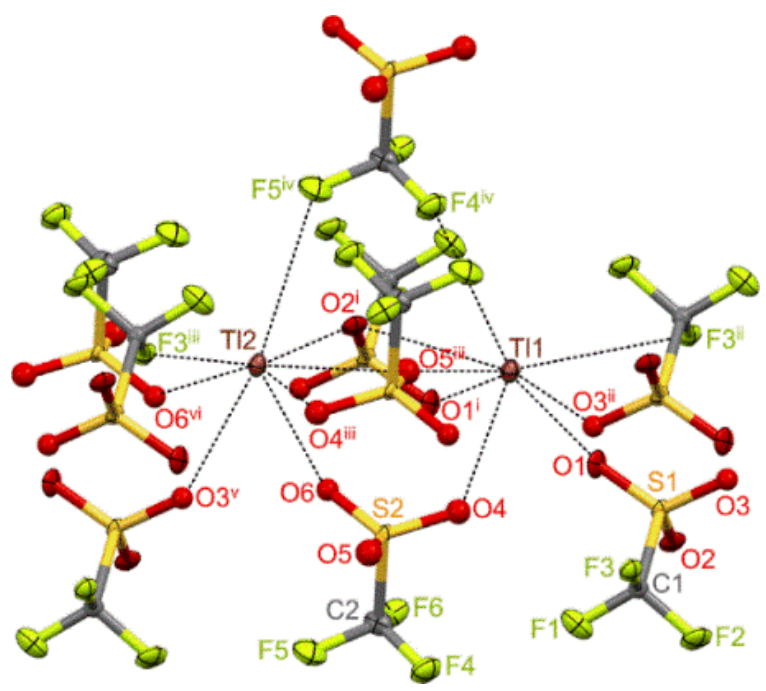

Figure 1. A fragment of the crystal structure of thallium(I) triflate showing the near surroundings around thallium(I) ions (atoms, except for O3-O6 and C1, shown as 50\% ellipsoids).

Table 1. Selected bond lengths, distances $(\AA)$, and angles $\left(^{\circ}\right)$ for thallium(I) triflate and its adduct with tropolone.

\begin{tabular}{|c|c|c|c|}
\hline \multicolumn{4}{|l|}{ Tl(OTf) } \\
\hline $\mathrm{Tl1} \cdots \mathrm{O} 1$ & $2.784(18)$ & $\mathrm{T} 12 \cdots \mathrm{O} 6$ & $2.782(16)$ \\
\hline $\mathrm{Tl} 1 \ldots \mathrm{O} 4$ & $2.721(14)$ & $\mathrm{T} 12 \cdots \mathrm{O} 2^{\mathrm{i}}$ & $2.798(16)$ \\
\hline $\mathrm{Tl} 1 \cdots \mathrm{O} 1^{\mathrm{i}}$ & $2.89(2)$ & $\mathrm{Tl} 2 \cdots \mathrm{O} 4^{\mathrm{iii}}$ & $3.06(2)$ \\
\hline $\mathrm{Tl} 1 \cdots \mathrm{O} 2^{\mathrm{i}}$ & $3.09(2)$ & $\mathrm{T} 12 \cdots \mathrm{O} 5^{\mathrm{iii}}$ & 2.91(2) \\
\hline $\mathrm{Tl} 1 \cdots \mathrm{O}^{\mathrm{ii}}$ & $2.98(2)$ & $\mathrm{Tl} 2 \cdots \mathrm{O}^{\mathrm{v}}$ & $2.85(1)$ \\
\hline $\mathrm{Tl} 1 \cdots \mathrm{O} 5^{\mathrm{iii}}$ & $2.85(2)$ & $\mathrm{Tl} 2 \cdots \mathrm{O}^{\mathrm{Vi}}$ & $2.93(2)$ \\
\hline Tl1 $\cdots$ F $^{\text {ii }}$ & $3.36(1)$ & $\mathrm{Tl} 2 \cdots \mathrm{F} 3^{\mathrm{iii}}$ & $3.22(1)$ \\
\hline $\mathrm{Tl} 1 \cdots \mathrm{F} 4^{\mathrm{iv}}$ & $3.43(1)$ & $\mathrm{Tl} 2 \cdots \mathrm{F} 5^{\mathrm{iv}}$ & $3.35(1)$ \\
\hline
\end{tabular}

Symmetry codes: (i) $-x,-y+1,-z+2$; (ii) $-x-1,-y+1,-z+2$;

(iii) $-x,-y+1,-z+1$; (iv) $x, y+1, z$; (v) $x+1, y, z-1$;

(vi) $-x+1,-y+1,-z+1$

\begin{tabular}{|c|c|c|c|}
\hline \multicolumn{4}{|c|}{ Tl(OTf)·Htrop } \\
\hline T11‥O1 & $2.722(2)$ & C1-O1 & $1.271(4)$ \\
\hline $\mathrm{T} 11 \cdots \mathrm{O} 3$ & $2.942(2)$ & $\mathrm{C} 2-\mathrm{O} 2$ & $1.348(4)$ \\
\hline $\mathrm{Tl} 1 \ldots \mathrm{O} 2^{\mathrm{i}}$ & $3.041(2)$ & O1-T11-O5 $5^{\mathrm{ii}}$ & $135.53(7)$ \\
\hline $\mathrm{Tl} \ldots \mathrm{O} 5^{\mathrm{ii}}$ & $2.934(2)$ & O3-Tl1-O1 $1^{\mathrm{iii}}$ & $147.97(7)$ \\
\hline $\mathrm{Tl1} \cdots \mathrm{O} 1^{\mathrm{iii}}$ & $2.744(2)$ & $\mathrm{O} 2^{\mathrm{i}}-\mathrm{Tl} 1-\mathrm{O} 4^{\mathrm{iv}}$ & $155.37(6)$ \\
\hline $\mathrm{Tl} 1 \ldots \mathrm{O} 1^{\mathrm{iv}}$ & $2.871(2)$ & & \\
\hline
\end{tabular}

The structure of the titled adduct consisted of thallium(I) triflate and tropolone at a molar ratio of 1:1. Each metal ion was surrounded by three tropolone molecules and three triflate anions. Each triflate and tropolone parts was connected with three thallium(I) ions. The metal ion in this structure was surrounded by six oxygen atoms (Figure 2). Three of them belonged to the three triflate groups. There were also three oxygen atoms from three tropolone molecules, including two from carbonyl groups and one from the hydroxyl

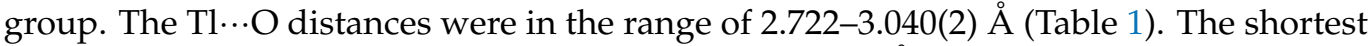

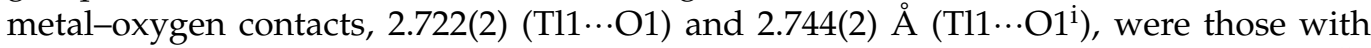
carbonyl groups of tropolone molecules. Slightly longer Tl-O bonds of 2.871(2) (T11 ..O $4^{\mathrm{ii}}$ ),

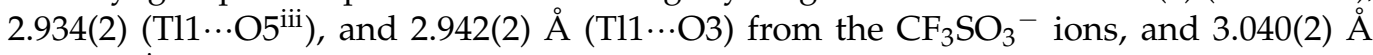
$\left(\mathrm{Tl} 1 \cdots \mathrm{O} 2^{\mathrm{iv}}\right)$ from the $\mathrm{OH}$ group of tropolone, completed the coordination sphere around 
thallium(I). These thallium-oxygen distances were much shorter than the calculated sum of the van der Waals radii of thallium and oxygen atoms (3.48 $\AA$ [37]). The arrangement of these six oxygen atoms around the metal center formed a strongly distorted octahedron (or distorted triangle antiprism). The presented structure may be considered to contain $\mathrm{Tl}^{+}$cations embedded within a network completed by the triflate anions and tropolone molecules. The presence of relatively weak Tl... O interactions suggested that this network was essentially ionic.

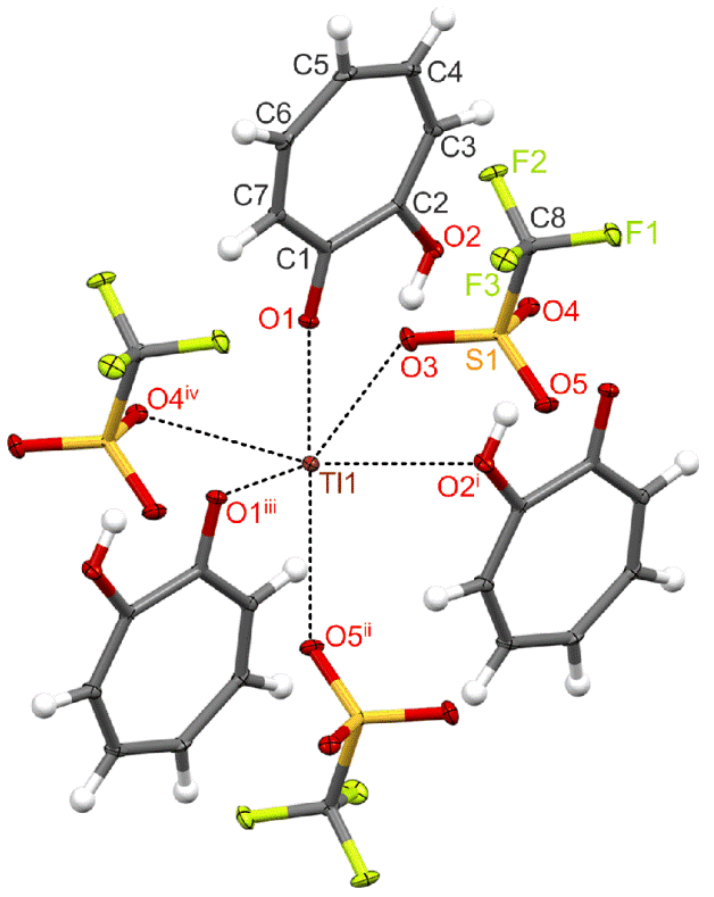

Figure 2. A fragment of the crystal structure of $\mathrm{Tl}(\mathrm{OTf}) \cdot$ Htrop adduct showing the near surroundings around the thallium(I) ion (nonhydrogen atoms shown as 50\% ellipsoids).

In the $\mathrm{Tl}(\mathrm{OTf}) \cdot$ Htrop structure, the tropolone molecules were not involved in the formation of $\mathrm{O}-\mathrm{H} \cdots \mathrm{O}$ hydrogen-bonded dimers, as they were in the case of pure tropolone [38]. However, it was stabilized by intermolecular $\mathrm{O} 2-\mathrm{H} 2 \cdots \mathrm{O} 4$ hydrogen bonds of 2.941(3) $\AA$ formed between tropolone molecules and triflate anions.

In the Cambridge Structural Database, there are several crystal structures that include thallium(I) triflate as a part of the structure [26,39-51].

\subsubsection{Complexes with Tropolone and 5-Methyltropolone: $\mathrm{Tl}$ (trop) (1) and $\mathrm{Tl}$ (5-metrop) (2)}

The molecular structures of the studied complexes with tropolone and its derivative substituted in position 5 by the methyl group are presented in Figure 3, and their selected bond parameters are listed in Table 2. The asymmetric units of the presented structures consisted of either a half or one molecule of the thallium(I) complex in $\mathbf{1}$ or $\mathbf{2}$, respectively. The crystal structures of these two compounds consisted of mononuclear Tl(trop) or Tl(5-metrop) units in which tropolones behaved as anionic bidentate ligands. Each thallium(I) ion was chelated by one ligand, resulting in a mean Tl-O bond length of 2.472(9) $\AA$ in 2 and 2.588(3) $\AA$ in 1. The bite angles, formed within five-membered chelate rings, equaled $61.1(1)$ and $65.7(3)^{\circ}$ for 1 and 2, respectively. The $\mathrm{C}-\mathrm{O}$ bonds in the range of 1.28-1.30 $\AA$ were distinguished within each ligand moiety. Thus, these distances were intermediate between those observed for double $\mathrm{C}=\mathrm{O}$ (ca. $1.25 \AA$ ) and single $\mathrm{C}-\mathrm{O}$ (ca. $1.34 \AA$ ) bonds in the free tropolone and 5-methyltropolone molecules [38,52]. 

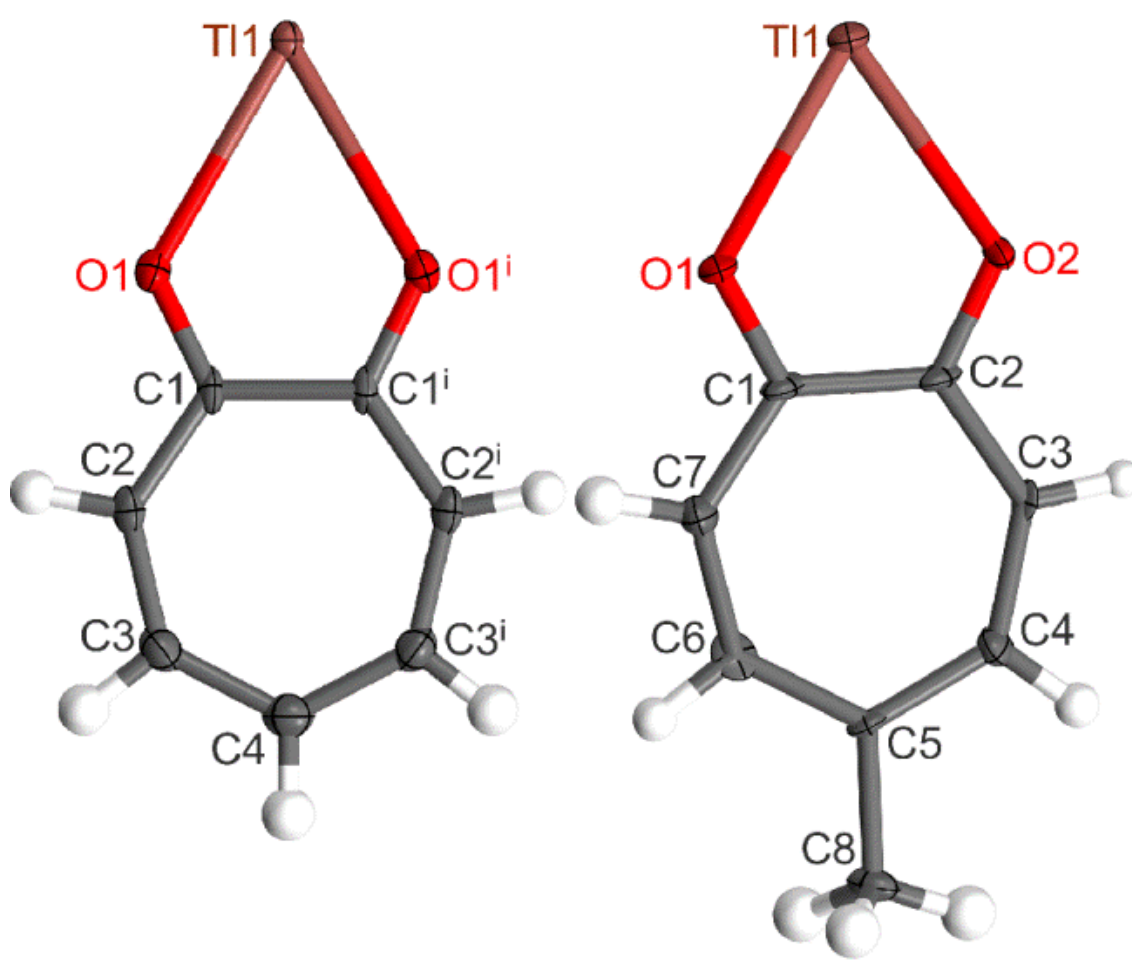

Figure 3. Molecular structures of $\mathrm{Tl}$ (trop) (1) (left) and Tl(5-metrop) (2) (right) (symmetry code: (i) $-x+1, y,-z+1.5)$. Nonhydrogen atoms are shown as $50 \%$ ellipsoids.

Table 2. Selected bond lengths, distances $(\AA)$, and angles $\left({ }^{\circ}\right)$ for thallium(I) chelates 1 and 2.

\begin{tabular}{|c|c|c|c|c|c|}
\hline \multicolumn{2}{|l|}{ Bond Lengths } & \multicolumn{2}{|l|}{ Distances } & \multicolumn{2}{|l|}{ Angles } \\
\hline \multicolumn{6}{|l|}{1} \\
\hline Tl1-O1 & $2.588(3)$ & $\mathrm{T} 11 \cdots \mathrm{O} 1^{\mathrm{ii}, \mathrm{iv}}$ & $2.906(3)$ & $\mathrm{O} 1-\mathrm{Tl} 1-\mathrm{O} 1^{\mathrm{i}}$ & $61.12(13)$ \\
\hline $\mathrm{Tl1}-\mathrm{O} 1^{\mathrm{i}}$ & $2.588(3)$ & $\mathrm{T} 11 \cdots \mathrm{O} 1^{\mathrm{iii}, \mathrm{v}}$ & $2.947(3)$ & & \\
\hline C1-O1 & $1.283(5)$ & & & & \\
\hline \multicolumn{6}{|c|}{$\begin{array}{l}\text { Symmetry codes: (i) }-x+1, y,-z+1.5 \text {; (ii) } x,-y+2, z+0.5 \text {; (iii) }-x+1.5,-y+2, z \text {; (iv) }-x+1 \text {, } \\
-y+2,-z+1 \text {; (v) } x-0.5,-y+2,-z+1.5\end{array}$} \\
\hline \multicolumn{6}{|l|}{2} \\
\hline T11-O2 & $2.446(6)$ & $\mathrm{T} 11 \cdots \mathrm{O} 2^{\mathrm{i}}$ & $2.873(10)$ & $\mathrm{O} 1-\mathrm{Tl1}-\mathrm{O} 2$ & $65.7(3)$ \\
\hline T11-O1 & $2.499(9)$ & $\mathrm{Tl} 1 \cdots \mathrm{O} 2^{\mathrm{ii}}$ & $2.888(10)$ & & \\
\hline $\mathrm{C} 2-\mathrm{O} 2$ & $1.284(17)$ & $\mathrm{Tl} 1 \cdots \mathrm{O} 1^{\mathrm{iii}}$ & $3.189(9)$ & & \\
\hline $\mathrm{C} 1-\mathrm{O} 1$ & $1.296(14)$ & & & & \\
\hline \multicolumn{6}{|c|}{ (i) $-x+0.5, y-0.5,-z+1$; (ii) $-x+0.5, y+0.5,-z+1$; (iii) $x, y+1, z$} \\
\hline
\end{tabular}

Coordination environments around chelated thallium(I) ions in the studied complexes, as shown in Figure 4, were completed by three or four additional oxygen atoms from neighboring molecules. These thallium-oxygen contacts were much shorter than the calculated sum of their van der Waals radii (3.48 $\AA$ [37]). The crystal structure of 1 was stabilized by a connection of the Tl(trop) units into layers (Figure 5), with two types of bridging Tl...O distances of 2.906(3) and 2.947(3) $\AA$ between adjacent molecules. The aromatic rings were directed outside of these layers. The molecules of $\mathbf{1}$ could also be considered as placed in planes intersecting at an angle of approximately $86^{\circ}$ with distances of $2.51 \AA$ between them. 


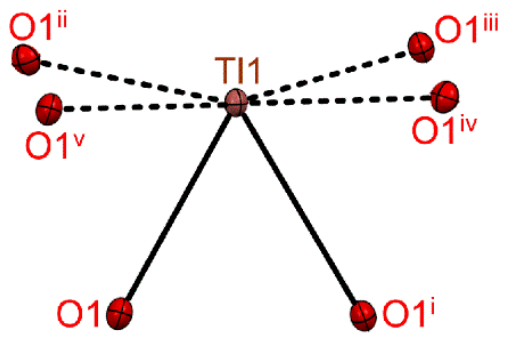

(a)

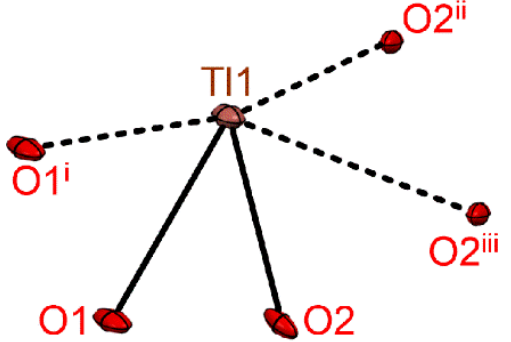

(b)

Figure 4. Coordination spheres of thallium(I) ions in complexes: (a) $\mathbf{1}$ and (b) $\mathbf{2}$ (symmetry codes as in Table 2). Solid and dashed lines indicate chelating bonds and intermolecular contacts, respectively.

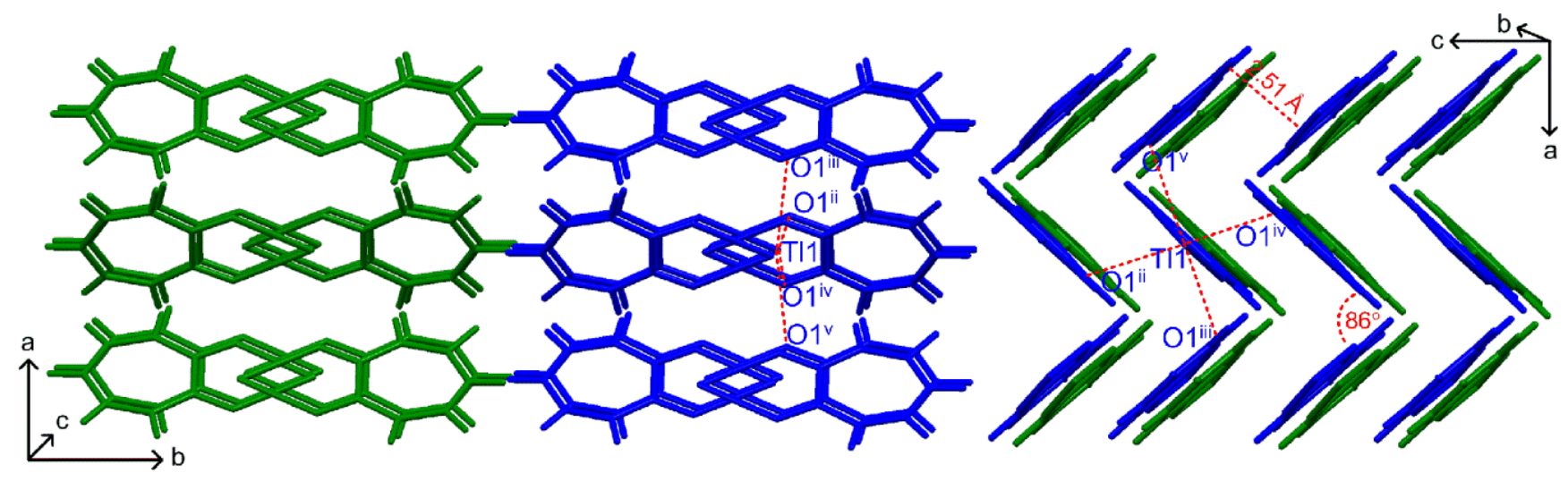

Figure 5. Two different views of the arrangement of Tl(trop) chelates in the extended structure of

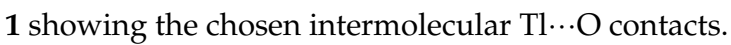

The crystal structure of 2 could be described as a connection of chelate units into chains extending along the $b$-axis (Figure 6). Within two adjacent chains the molecules of 2 were held together by bridging thallium-oxygen contacts of 2.873(10), 2.888(10), and 3.189(9) $\AA$, clearly longer than those observed for the chelating bonds. In addition, these pairs of chains were stabilized together by the presence of weak intermolecular hydrogen bonds

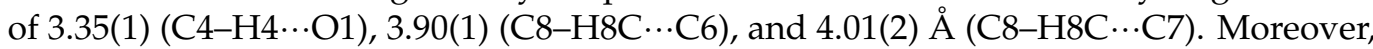
in contrast to 1 , the crystal structure of the complex with 5-methyltropolonato ligand was stabilized through intermolecular $\pi \cdots \pi$ interactions between neighboring aromatic rings, with distances of $3.84 \AA$ between their centroids. In addition, the shortest distance between metal atoms in 2 (3.843(2) $\AA$ ) was a bit less than twice the van der Waals radius of thallium (3.92 $\AA$ [37]), and could be considered as a weak metallophilic bonding. This distance was shorter than the analogous contacts in $\mathbf{1}$ (4.1822(2) and 4.1926(2) $\AA$ ). It was noteworthy that in contrast to 1 , the complex with 5-methyltropolone had a nonplanar chelate ring with the $\mathrm{Tl}$ atom lying about $0.38 \AA$ out of plane formed by the remaining atoms. It is worth adding that only a few complexes of 5-methyltropolone with bismuth(III) ion have been structurally characterized until now [15].

\subsubsection{Complexes with Hinokitiol: $\mathrm{Tl}\left(\right.$ hino) (3) and $\left\{\mathrm{Tl} @[\mathrm{Tl}(\mathrm{hino})]_{6}\right\}$ (OTf) (4)}

The crystal structure of $\mathbf{3}$ contained four $\mathrm{Tl}$ (hino) molecules in the asymmetric unit (Figure 7), while the asymmetric part of 4 consisted of six such chelate molecules and one thallium(I) cation neutralized by a triflate anion (Figure 8). This $\mathrm{Tl}^{+}$ion (Tl7) was isolated from the $\mathrm{CF}_{3} \mathrm{SO}_{3}{ }^{-}$ion by six $\mathrm{Tl}$ (hino) molecules, which formed a specific cage for the free metal cation. 


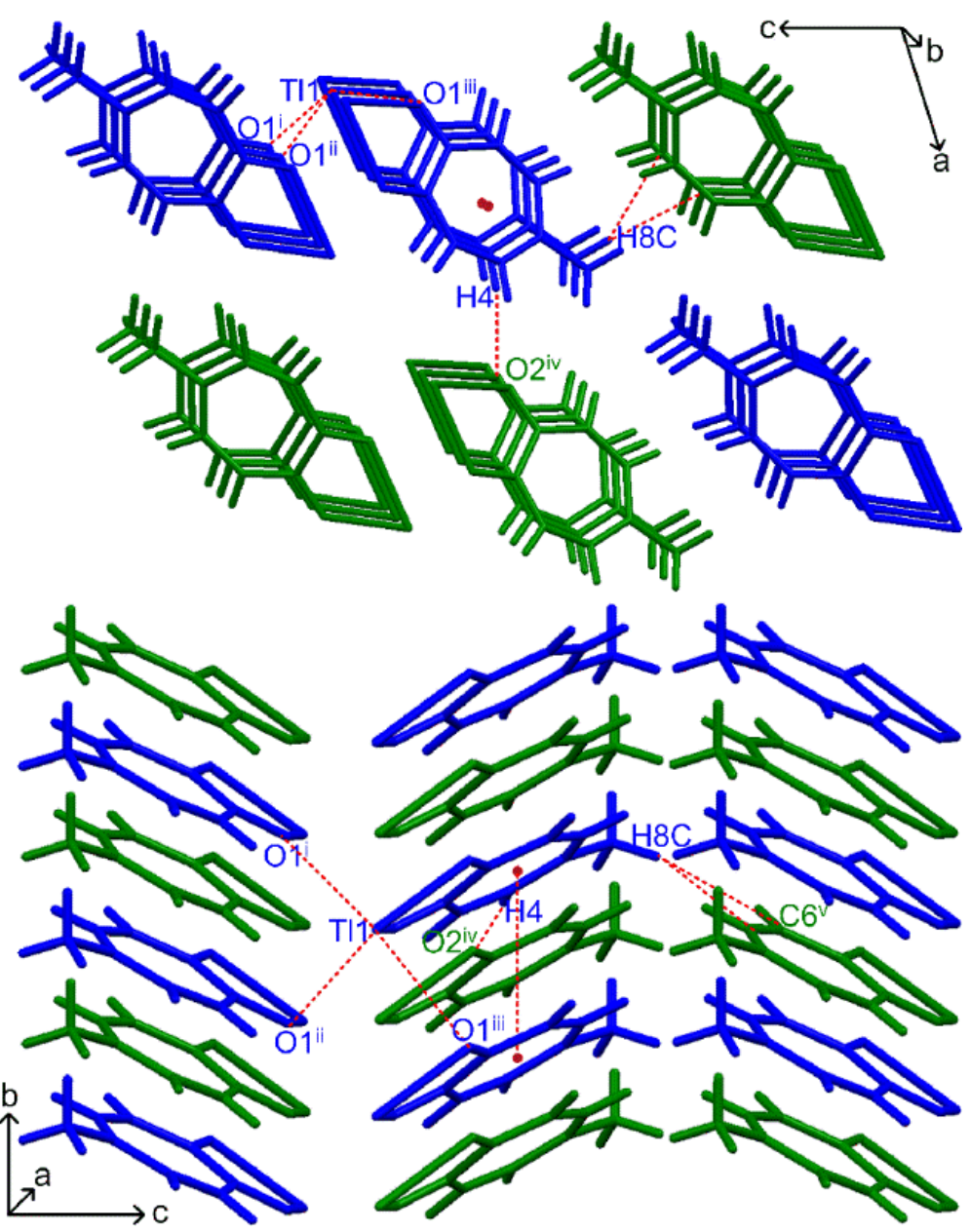

Figure 6. Two different views of the arrangement of Tl(5-metrop) chelates in the extended structure of 2 showing the chosen intermolecular contacts.

Each chelated thallium(I) ion in both compounds was surrounded in its closest environment by five or six oxygen atoms (Figure 9). Two of them belonged to the hinokitiolato ligand, which formed a five-membered chelate ring. There were also three or four additional oxygen atoms from neighboring hino ${ }^{-}$ligands, while two such oxygen atoms could be distinguished only for T12 in 4 . For the chelating Tl-O interactions, a broad bond distance distribution (ranges: 2.464-2.669 $\AA$ for 3 and 2.472-2.662 $\AA$ for 4) was observed in both presented compounds (Tables 3 and 4). The mean $\mathrm{Tl}-\mathrm{O}_{(\text {hino) }}$ bond length for the respective chelates in 3 were equal to 2.476(3), 2.571(3), 2.591(3), and 2.608(3) ̊ for the T13, T12, T11, and Tl4 atoms, respectively. In turn, such mean Tl-O $\mathrm{O}_{(\text {hino) }}$ distances, 2.520(5), 2.504(6), 2.572(5), 2.505(5), 2.578(6), and 2.552(5) A for the atoms from Tl1 to Tl6, respectively, could be distinguished for complexes in 4.

In the presented compounds with a hinokitiol ligand, some part of the thallium(I) ions, similarly to 2 , remained clearly outside the plane of the chelate ring, with a displacement value of approximately 0.59 and $0.64 \AA$ for the Tl4 and Tl 3 atoms in 3 and 0.27 and $0.54 \AA$ for the T15 and T13 atoms in 4 . 


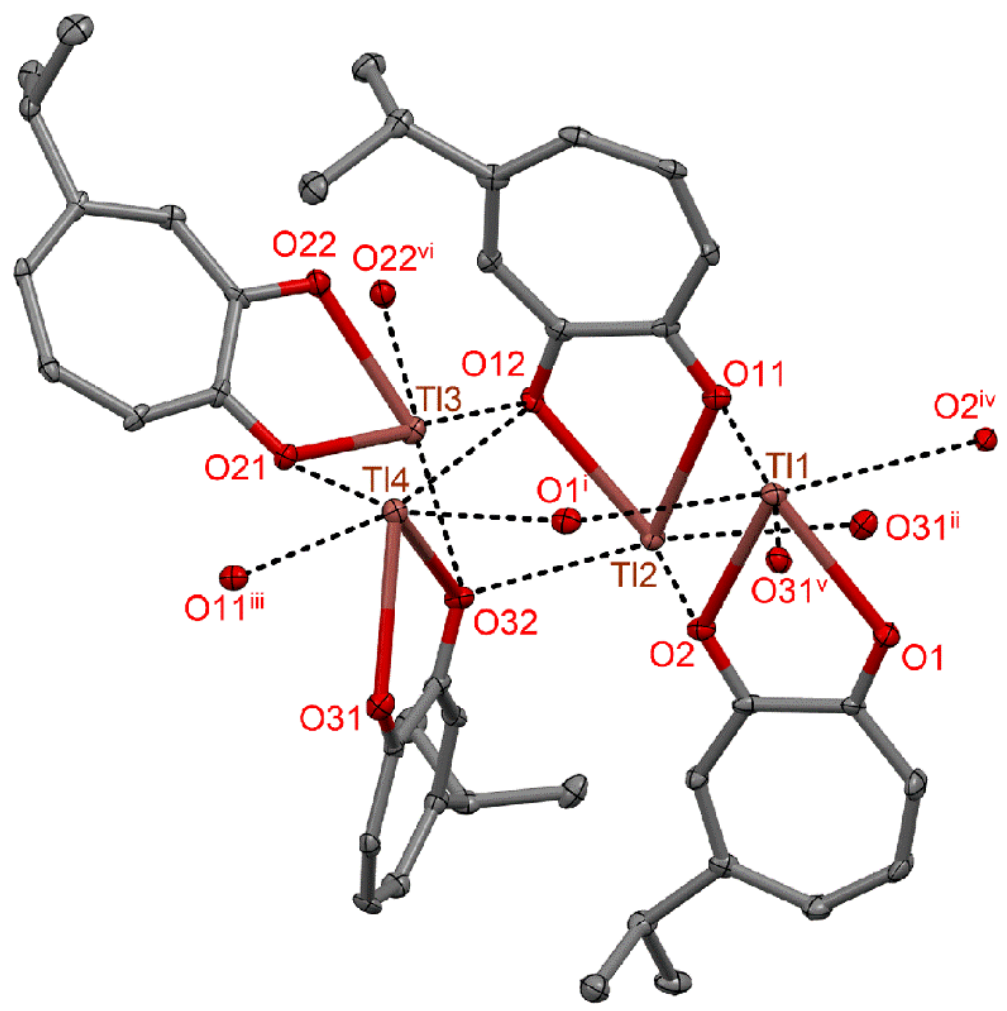

Figure 7. Asymmetric unit of 3 with intermolecular contacts between Tl(hino) molecules (atoms shown as $50 \%$ ellipsoids; hydrogen atoms were omitted for clarity).

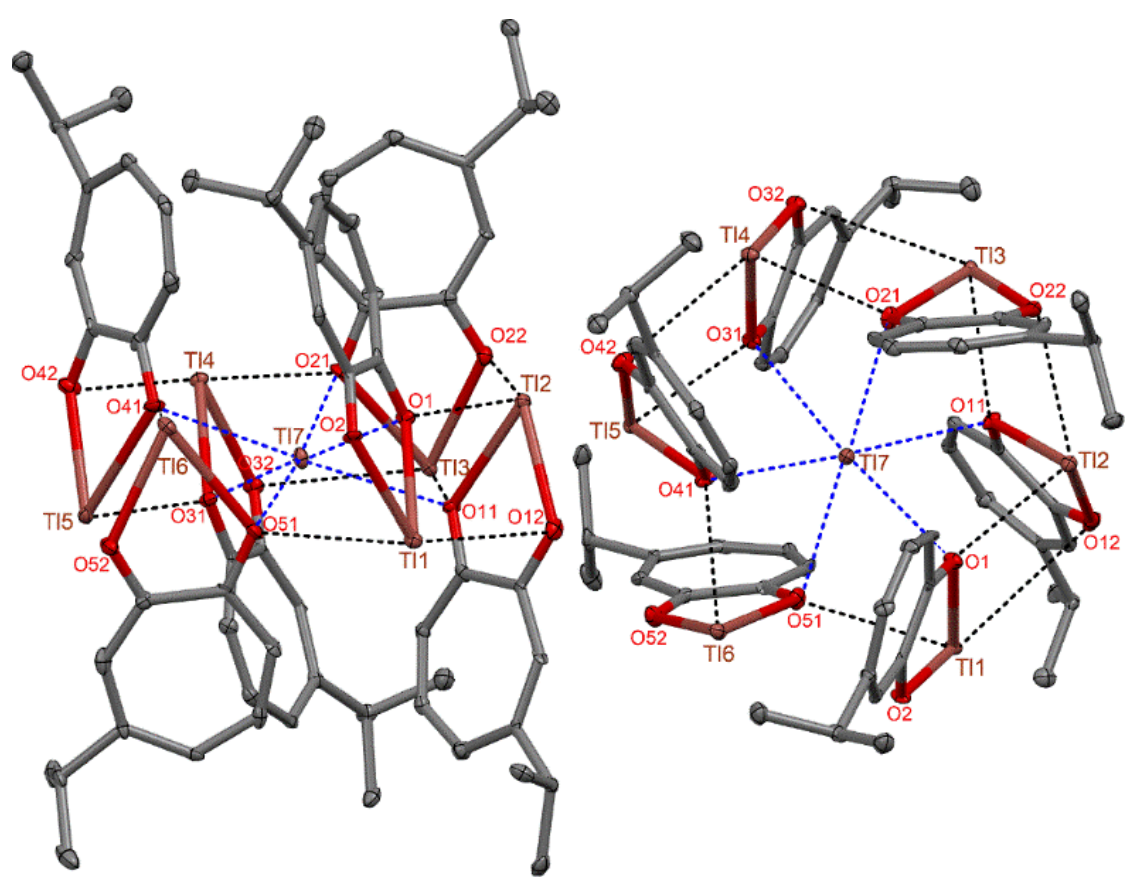

Figure 8. Asymmetric unit of 4 in two different views showing intermolecular contacts between $\mathrm{Tl}\left(\right.$ hino) molecules (black dotted lines) and the shortest distances for the free $\mathrm{Tl}^{+}$ion (blue dotted lines). Atoms are shown as 50\% ellipsoids. Hydrogen atoms and the triflate ion were omitted for clarity. 


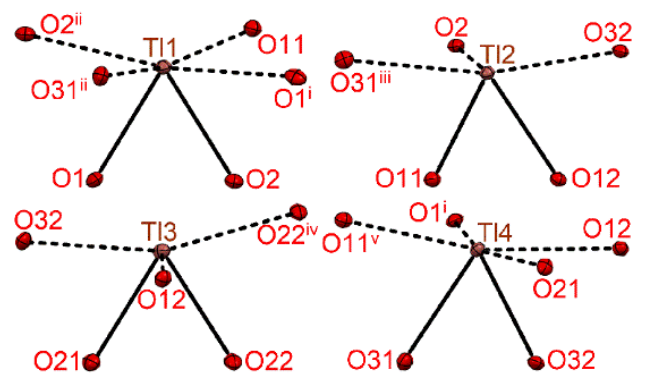

(a)

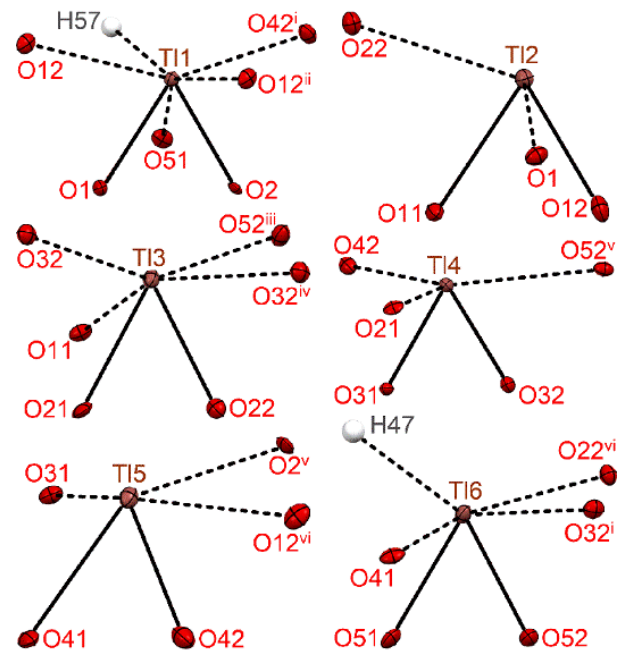

(b)

Figure 9. Coordination spheres of thallium(I) ions in compounds (a) 3 (symmetry codes as in Table 3) and (b) 4 (symmetry codes as in Table 4). Solid and dashed lines indicate chelating bonds and intermolecular contacts, respectively.

Table 3. Selected bond lengths, distances $(\AA)$, and angles $\left(^{\circ}\right)$ for compound 3.

\begin{tabular}{|c|c|c|c|}
\hline \multicolumn{4}{|l|}{ Bond Lengths } \\
\hline Tl1-O1 & $2.616(3)$ & $\mathrm{C} 1-\mathrm{O} 1$ & $1.261(5)$ \\
\hline T11-O2 & $2.566(3)$ & $\mathrm{C} 2-\mathrm{O} 2$ & $1.287(6)$ \\
\hline Tl2-O11 & $2.538(3)$ & C11-O11 & $1.266(6)$ \\
\hline T12-O12 & $2.604(3)$ & C12-O12 & $1.269(5)$ \\
\hline $\mathrm{Tl} 3-\mathrm{O} 21$ & $2.464(3)$ & $\mathrm{C} 21-\mathrm{O} 21$ & $1.278(6)$ \\
\hline T13-O22 & $2.487(3)$ & $\mathrm{C} 22-\mathrm{O} 22$ & $1.266(6)$ \\
\hline $\mathrm{Tl4}-\mathrm{O} 31$ & $2.669(4)$ & $\mathrm{C} 31-\mathrm{O} 31$ & $1.268(6)$ \\
\hline T14-O32 & $2.547(3)$ & C32-O32 & $1.274(5)$ \\
\hline \multicolumn{4}{|l|}{ Distances } \\
\hline T11‥O11 & $2.867(3)$ & $\mathrm{Tl} 3 \cdots \mathrm{O} 12$ & $2.755(3)$ \\
\hline $\mathrm{Tl} 1 \cdots \mathrm{O} 1^{\mathrm{i}}$ & $2.930(4)$ & $\mathrm{Tl} 3 \cdots \mathrm{O} 32$ & $2.986(3)$ \\
\hline $\mathrm{T} 11 \cdots \mathrm{O} 2^{\mathrm{ii}}$ & 3.011(3) & $\mathrm{T} 13 \cdots \mathrm{O} 22^{\mathrm{iv}}$ & $3.322(3)$ \\
\hline $\mathrm{Tl} 1 \cdots \mathrm{O} 31^{\mathrm{ii}}$ & $3.044(3)$ & $\mathrm{T} 14 \cdots \mathrm{O} 21$ & $2.726(3)$ \\
\hline $\mathrm{T} 12 \cdots \mathrm{O} 2$ & $2.719(3)$ & $\mathrm{Tl} 14 \cdots \mathrm{O} 11^{\mathrm{v}}$ & $2.971(3)$ \\
\hline $\mathrm{Tl} 2 \cdots \mathrm{O} 32$ & $2.803(3)$ & $\mathrm{Tl} 4 \cdots \mathrm{O} 12$ & 2.971(3) \\
\hline $\mathrm{Tl} 2 \cdots \mathrm{O} 31^{\mathrm{iii}}$ & $2.989(4)$ & $\mathrm{Tl} 14 \cdots \mathrm{O} 1^{\mathrm{i}}$ & $3.030(3)$ \\
\hline \multicolumn{4}{|l|}{ Angles } \\
\hline O1-T11-O2 & $61.0(1)$ & $\mathrm{O} 21-\mathrm{Tl} 3-\mathrm{O} 22$ & $64.5(1)$ \\
\hline O11-T12-O12 & 61.4(1) & O31-T14-O32 & $60.2(1)$ \\
\hline
\end{tabular}


Table 4. Selected bond lengths, distances $(\AA)$, and angles $\left(^{\circ}\right)$ for compound 4 .

\begin{tabular}{|c|c|c|c|c|c|c|c|}
\hline \multicolumn{4}{|l|}{ Bond Lengths } & \multicolumn{4}{|l|}{ Distances } \\
\hline Tl1-O1 & $2.567(5)$ & C1-O1 & $1.297(9)$ & $\mathrm{Tl} 1 \cdots \mathrm{O} 42^{\mathrm{i}}$ & $2.898(6)$ & $\mathrm{Tl} 5 \cdots \mathrm{O} 31$ & $2.712(5)$ \\
\hline $\mathrm{T} 11-\mathrm{O} 2$ & $2.472(5)$ & $\mathrm{C} 2-\mathrm{O} 2$ & $1.259(8)$ & $\mathrm{Tl} 1 \cdots \mathrm{O} 12^{\mathrm{ii}}$ & $2.905(6)$ & $\mathrm{T} 15 \cdots \mathrm{O} 12^{\mathrm{vi}}$ & $3.002(6)$ \\
\hline Tl2-O11 & $2.532(5)$ & C11-O11 & $1.262(9)$ & T11‥O51 & $3.016(6)$ & $\mathrm{T} 15 \cdots \mathrm{O} 2^{\mathrm{v}}$ & $3.017(6)$ \\
\hline $\mathrm{Tl2}-\mathrm{O} 12$ & $2.477(6)$ & C12-O12 & $1.280(9)$ & $\mathrm{Tl1} \cdots \mathrm{O} 12$ & $3.446(6)$ & 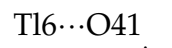 & $2.831(6)$ \\
\hline $\mathrm{T} 13-\mathrm{O} 21$ & $2.652(5)$ & $\mathrm{C} 21-\mathrm{O} 21$ & $1.303(9)$ & $\mathrm{Tl} 2 \cdots \mathrm{O} 1$ & $2.772(7)$ & $\mathrm{Tl} 6 \cdots \mathrm{O} 32^{\mathrm{i}}$ & $2.960(6)$ \\
\hline $\mathrm{Tl} 3-\mathrm{O} 22$ & $2.492(5)$ & $\mathrm{C} 22-\mathrm{O} 22$ & $1.284(9)$ & $\mathrm{T} 12 \cdots \mathrm{O} 22$ & $2.947(6)$ & $\mathrm{T} 16 \cdots \mathrm{O} 22^{\mathrm{vi}}$ & $3.019(6)$ \\
\hline Tl4-O31 & $2.522(5)$ & C31-O31 & $1.293(9)$ & $\mathrm{Tl} 3 \cdots \mathrm{O} 11$ & $2.836(6)$ & Tl7 $\cdots \mathrm{O} 41$ & $2.868(6)$ \\
\hline Tl4-O32 & $2.488(5)$ & C32-O32 & $1.273(8)$ & $\mathrm{Tl} 3 \cdots \mathrm{O} 52^{\mathrm{iii}}$ & $2.867(6)$ & $\mathrm{T} 17 \ldots \mathrm{O} 1$ & $2.878(6)$ \\
\hline Tl5-O41 & $2.662(5)$ & C41-O41 & $1.271(9)$ & $\mathrm{Tl} 3 \cdots \mathrm{O} 32^{\mathrm{iv}}$ & $2.985(6)$ & 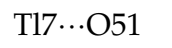 & $2.897(6)$ \\
\hline $\mathrm{Tl} 15-\mathrm{O} 42$ & $2.495(6)$ & $\mathrm{C} 42-\mathrm{O} 42$ & $1.287(9)$ & $\mathrm{Tl} 3 \cdots \mathrm{O} 32$ & $3.430(6)$ & $\mathrm{T} 17 \cdots \mathrm{O} 21$ & $2.906(6)$ \\
\hline Tl6-O51 & $2.621(5)$ & C51-O51 & $1.265(9)$ & $\mathrm{Tl} 14 \cdots \mathrm{O} 21$ & $2.822(6)$ & Tl7‥O31 & $2.911(6)$ \\
\hline Tl6-O52 & $2.483(5)$ & C52-O52 & $1.279(9)$ & $\mathrm{T} 14 \cdots \mathrm{O} 42$ & $3.075(6)$ & $\mathrm{Tl}$...O 11 & $2.979(6)$ \\
\hline Angles & & & & $\mathrm{T} 4 \cdots \mathrm{O} 52^{\mathrm{v}}$ & $3.410(5)$ & & \\
\hline O1-T11-O2 & $63.9(2)$ & O31-T14-O32 & $63.8(2)$ & & & & \\
\hline O11-T12-O12 & $63.1(2)$ & O41-T15-O42 & $61.0(2)$ & & & & \\
\hline $\mathrm{O} 21-\mathrm{Tl} 3-\mathrm{O} 22$ & $61.7(2)$ & O51-T16-O52 & $62.7(2)$ & & & & \\
\hline
\end{tabular}

Symmetry codes: (i) $-\mathrm{x}+1, \mathrm{y}-0.5,-\mathrm{z}+0.5$; (ii) $-\mathrm{x}+1,-\mathrm{y},-\mathrm{z}+1$; (iii) $\mathrm{x},-\mathrm{y}+0.5, \mathrm{z}+0.5$; (iv) $-\mathrm{x}+1,-\mathrm{y}+1$, $-\mathrm{z}+1 ;(\mathrm{v})-\mathrm{x}+1, \mathrm{y}+0.5,-\mathrm{z}+0.5 ;(\mathrm{vi}) \mathrm{x},-\mathrm{y}+0.5, \mathrm{z}-0.5$.

All Tl(hino) complexes in the extended crystal structures were stabilized by weaker thallium-oxygen contacts between neighboring molecules. These additional interactions are listed in Tables 3 and 4 . Most of such bridging $\mathrm{Tl} \cdots \mathrm{O}$ distances in 3 and 4 remained in the range of 2.72-3.08 $\AA$, much shorter than the $3.48 \AA$ calculated for the sum of the van der Waals radii of both atoms [37]. A few longer contacts of approximately $3.41,3.43$, and $3.45 \AA$ could also be found in 4 . In addition, some intermolecular anagostic $\mathrm{Tl} \cdots \mathrm{H}-\mathrm{C}$ interactions

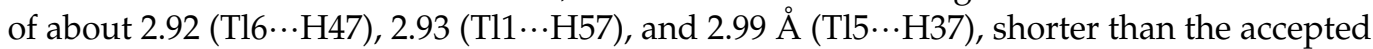
sum of the van der Waals radii of $\mathrm{Tl}$ and $\mathrm{H}$ atoms (3.06 $\AA$ [37]), appeared to contribute to the stability of the crystal packing in 4 . The corresponding $\mathrm{Tl}-\mathrm{H}-\mathrm{C}$ angles associated with these contacts were 123 (for Tl6), 133 (T11), and $122^{\circ}$ (Tl5). These anagostic Tl $\cdots \mathrm{H}-\mathrm{C}$ interactions found in 4 were shorter than those for other thallium(I) systems presented recently $[53,54]$.

The position of the free $\mathrm{Tl}^{+}$ion in 4 was stabilized by six thallium-oxygen contacts with a mean Tl... distance of 2.906(6) $\AA$ and a narrow distance distribution (range: 2.868-2.979(6) $\AA$ ) showing a distorted octahedral configuration around this metal center. In the crystal structures of both compounds, the $\mathrm{Tl}($ hino) molecules were arranged into layers (Figure 10) with isopropyl groups directed outside of them. In addition, the triflate anions were placed between these layers in 4 .

The shortest $\mathrm{Tl}$... Tl distances between neighboring $\mathrm{Tl}$ (hino) molecules in 3 were equal

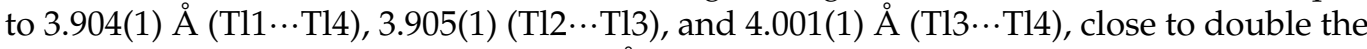
van der Waals radius of thallium (3.92 $\AA$ [37]), and they could be considered as a weak metallophilic bonding. Similar contacts in 4 were a bit longer, in the range of $4.10-4.23 \AA$, and were formed between the free thallium(I) ion and other metal atoms belonging to the adjacent $\mathrm{Tl}$ (hino) chelates. The closest $\mathrm{Tl}$...Tl distances between neighboring complex molecules in 4 were even longer, above $4.25 \AA$.

Several hinokitiolato-metal complexes have been structurally characterized and tested against antimicrobial activities $[7,55]$. 


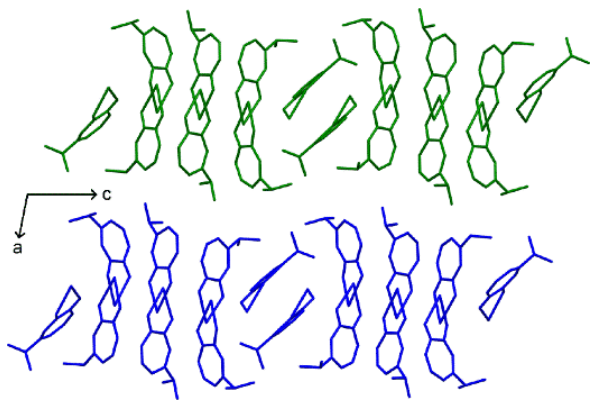

(a)

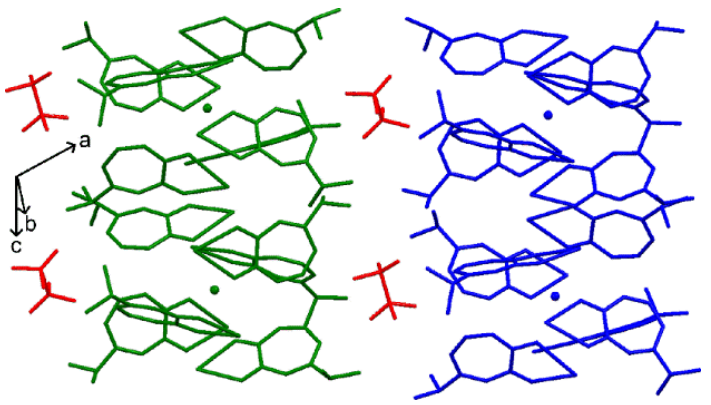

(b)

Figure 10. The arrangement of molecules in the extended structures of (a) 3 and (b) 4 .

\subsection{Spectroscopic Analysis}

Comparison of the IR spectrum of the $\mathrm{Tl}(\mathrm{OTf}) \cdot \mathrm{Htrop}$ adduct with the spectra of pure tropolone and thallium(I) triflate components (Figures S1-S3) allowed us to select two groups of the IR bands corresponding to (i) tropolone and to (ii) triflate anion vibrations. The former dominated the spectra of the described system. The broad band at $3170 \mathrm{~cm}^{-1}$ could be assigned to the tropolone $\mathrm{OH}$ stretching vibrations. The bending and torsional $\mathrm{OH}$ modes could be distinguished at 1254 and $759 \mathrm{~cm}^{-1}$ [56]. The asymmetric and symmetric stretching tropolone $\mathrm{C}=\mathrm{O}$ bands could be found at 1607 and $1532 \mathrm{~cm}^{-1}$. The main IR bands of the triflate ion were those of the $\mathrm{SO}_{3}$ and $\mathrm{CF}_{3}$ group vibrations located at 1218,1154 , and $1021 \mathrm{~cm}^{-1}$.

The juxtaposition of the IR spectra of tropolone ligands with the reciprocal thallium(I) complexes (Figures S3-S9) showed that the tropolonate bands dominated the spectra. The thallium(I) chelates were formed through the tropolonate $\mathrm{C}=\mathrm{O}$ and $\mathrm{O}-\mathrm{H}$ moieties, which were corroborated by the absence of the stretching and bending $\mathrm{OH}$ bands at 3187 and 1264,3190 and 1261, or 3203 and $1268 \mathrm{~cm}^{-1}$ in free tropolone, 5-methyltropolone, or hinokitiol, respectively. This was accompanied by a decrease in the double bond character of the $\mathrm{C}=\mathrm{O}$ group coordinated to the metal ion, manifested by a downshift of the $\mathrm{C}=\mathrm{O}$ bands at 1603 and 1543 (Htrop) or 1619 and $1542 \mathrm{~cm}^{-1}$ (5-meHtrop), respectively, to 1588 and $1492 \mathrm{~cm}^{-1}$ or 1605 and $1508 \mathrm{~cm}^{-1}$ in the thallium(I) complexes. The analogous hinokitiol bands at 1606 and $1541 \mathrm{~cm}^{-1}$ shifted to 1582 and $1490 \mathrm{~cm}^{-1}$ in the thallium(I) hinokitiolate complexes (3 and 4 ).

The UV-vis spectra of tropolone ligands and the 1-4 thallium(I) complexes in the methanol solutions were similar to each other (Figure S10). Indeed, as the free ligands, 1-4 exhibited intense absorptions below $250 \mathrm{~nm}$ and two distinct bands in the 300-420 nm region: more intense at $332 \mathrm{~nm}$ and weaker at $395 \mathrm{~nm}$. The additional band could be seen between them as a shoulder at $c a .370 \mathrm{~nm}$. In this very region, the bands of complexes were redshifted and more distinct than those of the pure ligands.

The photophysical data of thallium(I) chelates studied in methanol and the solid state are summarized in Table 5, while the emission and absorption profiles can be found in Figure S11. The fluorescence spectra of all compounds in methanol solution showed very broad profiles, from around $380 \mathrm{up}$ to $550 \mathrm{~nm}$ (left panels of Figure S11). In the solid state, two bands around 420 and $462 \mathrm{~nm}$ (emission spectra) and 375 and $420 \mathrm{~nm}$ (excitation spectra) were observed (right panels of Figure S11). Only 2 exhibited fluorescence that was redshifted $(502 \mathrm{~nm})$ in comparison to the other thallium(I) chelates. The fluorescence decays had two components in the solid state: a long-lived one, with a lifetime around $15 \mathrm{~ns}$; and the other short-lived, with a lifetime around $0.15 \mathrm{~ns}$. In the solid-state measurements, the highest average lifetime was found for $\mathbf{4}$, and the shortest for $\mathbf{1}$. Interestingly, in the methanol solution, this trend was reversed. In methanol, the fluorescence quantum yields $\varphi$ of the thallium(I) chelates were relatively high. Indeed, the complexes with tropolone and 5 -methyltropolone exhibited 3 or 4 times higher quantum yields than for complexes with hinokitiol. Furthermore, all the studied complexes displayed very short-lived emissions $\tau$ 
if compared to, e.g., thallium(I) acetyloacetonate [57]. The photophysical data of the two hinokitiol complexes ( 3 and 4 ) were almost the same.

Table 5. Photophysical data of thallium(I) chelates.

\begin{tabular}{|c|c|c|c|c|}
\hline Compound & Matrix & $\lambda_{\text {abs max }} / \lambda_{\text {em max }}[\mathrm{nm}]$ & $\varphi[\%]$ & $\tau[\mathrm{ns}]$ \\
\hline \multirow{2}{*}{1} & $\mathrm{MeOH}$ & $393 / 421$ & $0.20^{\mathrm{a}}$ & 0.24 \\
\hline & solid & $375,434 / 411,461$ & - & $8.2(31 \%), 0.19(69 \%)$ \\
\hline \multirow{2}{*}{2} & $\mathrm{MeOH}$ & $402 / 432$ & $0.27^{\mathrm{b}}$ & 0.22 \\
\hline & solid & $375,460 / 430,502$ & - & $12(57 \%), 0.15(43 \%)$ \\
\hline \multirow[b]{2}{*}{3} & $\mathrm{MeOH}$ & $390 / 419$ & $0.06^{\mathrm{b}}$ & 0.12 \\
\hline & solid & $377,420 / 417,463$ & - & $16(62 \%), 0.12(38 \%)$ \\
\hline \multirow{2}{*}{4} & $\mathrm{MeOH}$ & $390 / 421$ & $0.06^{\mathrm{b}}$ & 0.12 \\
\hline & solid & $372,426 / 415,462$ & - & $16(61 \%), 0.34(39 \%)$ \\
\hline
\end{tabular}

${ }^{\mathrm{a}}$ Quinine sulfate in $0.5 \mathrm{M} \mathrm{H}_{2} \mathrm{SO}_{4} ;{ }^{\mathrm{b}}$ perylene in cyclohexane as standards.

The NMR data of all compounds in solution are gathered in Figures S12-S17. The ${ }^{1} \mathrm{H}$ NMR spectra of thallium(I) compounds showed three (Tl(OTf).Htrop and 1), five (2), or six (3 and 4) proton signals originating from the respective ligand. In the case of the adduct, the signal of the $\mathrm{OH}$ proton in Htrop was not registered. However, for the $[\mathrm{Bi} \text { (trop) })_{2}$ (Htrop) $\left.\left(\mathrm{CF}_{3} \mathrm{SO}_{3}\right)\right]$ and $[\mathrm{Pb} \text { (trop) })_{2}$ (Htrop)] complexes, a broad proton signal of the tropolone $\mathrm{OH}$ group was previously observed by us at around $10 \mathrm{ppm} \mathrm{[16].} \mathrm{In} \mathrm{the}{ }^{205} \mathrm{Tl}$ $\mathrm{NMR}$ spectra, the $\mathrm{Tl}^{+}$signal from the thallium(I) triflate and its adduct with tropolone was located at $370 \mathrm{ppm}$ (Figure S18). Complexation by tropolonates broadened the signal and shifted it to the lower field by over $1000 \mathrm{ppm}$. For 4, 1, 3, and 2, the ${ }^{205} \mathrm{Tl}$ NMR signals were observed at 1373, 1416, 1507, and 1574 ppm, respectively (Figure S18). Surprisingly, the ${ }^{205} \mathrm{Tl}$ NMR signals of the Tl(hino) chelates 3 and 4 differed by about $130 \mathrm{ppm}$. Due to the relatively low concentration of the uncoordinated thallium(I) ion in 4 , its signal could not be registered.

\subsection{Antimicrobial Activity}

The in vitro antimicrobial activity of thallium(I) tropolonate complexes and free tropolone ligands was compared with the selected lead(II) and bismuth(III) analogues characterized chemically earlier [14,15,17]. The activity of three thallium(I) (Tl(trop), $\mathrm{Tl}$ (5-metrop) and $\mathrm{Tl}\left(\text { hino)), two lead(II) }(\mathrm{Pb} \text { (hino })_{2} \text { and } \mathrm{Pb} \text { (trop) }\right)_{2}$ ), and three bismuth(III) $\left(\left[\mathrm{Bi}_{2}(\text { trop })_{4}\left(\mathrm{NO}_{3}\right)_{2}\right]_{\mathrm{n}}, \mathrm{Bi} \text { (trop }\right)_{3}$ and $\left.\mathrm{Bi}(5 \text {-metrop })_{2}\left(\mathrm{NO}_{3}\right)\right)$ complexes and their ligands against two groups of reference microorganisms were examined. The first one was composed of strains recommended by the European Committee on Antimicrobial Susceptibility Testing (EUCAST) for the antibiotics quality control [58]. This group contained microorganisms representative of the most frequent infections in humans: Escherichia coli ATCC 25922, Pseudomonas aeruginosa ATCC 27853, Staphylococcus aureus ATCC 29213, and Enterobacter faecalis ATCC 29212. The second group consisted of microorganisms indicated by the United States Pharmacopeia to test the antimicrobial effectiveness [59]. It contained the following strains: E. coli ATCC 8739, P. aeruginosa ATCC 9027, S. aureus ATCC 6538, and Candida albicans ATCC 10231. The minimum inhibitory concentration (MIC) values for the two groups of bacterial species were compared with the results included in EUCAST breakpoint tables for interpretation of MICs (Table 6). 
Table 6. MICs/MBCs * or MFCs * of thallium(I), lead(II), and bismuth(III) complexes and free ligands obtained for reference strains.

\begin{tabular}{|c|c|c|c|c|c|c|c|c|}
\hline & $\begin{array}{c}\text { E. coli ATCC } \\
8739\end{array}$ & $\begin{array}{c}\text { E. coli ATCC } \\
25922\end{array}$ & $\begin{array}{c}\text { S. aureus } \\
\text { ATCC } \\
6538\end{array}$ & $\begin{array}{c}\text { S. aureus } \\
\text { ATCC } 29213\end{array}$ & $\begin{array}{c}\text { P. aeruginosa } \\
\text { ATCC } \\
9027\end{array}$ & $\begin{array}{l}P . \text { aeruginosa } \\
\text { ATCC } 27853\end{array}$ & $\begin{array}{c}\text { E. faecalis } \\
\text { ATCC } 29212\end{array}$ & $\begin{array}{c}\text { C. albicans } \\
\text { ATCC } 10232\end{array}$ \\
\hline $\mathrm{Tl}$ (trop) & 256/ND & $128 / \mathrm{ND}$ & 256/ND & $512 / \mathrm{ND}$ & 256/ND & $128 / \mathrm{ND}$ & $512 / \mathrm{ND}$ & $128 / \mathrm{ND}$ \\
\hline $\mathrm{Pb}$ (trop) $)_{2}$ & $128 / \mathrm{ND}$ & $64 / \mathrm{ND}$ & $128 / \mathrm{ND}$ & $128 / \mathrm{ND}$ & $512 / N D$ & $256 / N D$ & $64 / \mathrm{ND}$ & 64/ND \\
\hline $\mathrm{Bi}(\text { trop })_{3}$ & $16 / 256$ & $8 / 16$ & $16 / 16$ & $8 / 16$ & $32 / 64$ & $16 / 64$ & 8/ND & $512 / \mathrm{ND}$ \\
\hline$\left[\mathrm{Bi}_{2}(\text { trop })_{4}\left(\mathrm{NO}_{3}\right)_{2}\right]_{\mathrm{n}}$ & $16 / N D$ & $16 / 16$ & $16 / 16$ & $8 / 16$ & $32 / 64$ & $32 / 64$ & $16 / N D$ & $128 / \mathrm{ND}$ \\
\hline Htrop & $128 / \mathrm{ND}$ & $64 / \mathrm{ND}$ & 256/ND & $128 / \mathrm{ND}$ & 256/ND & 256/ND & $256 / 256$ & $64 / 512$ \\
\hline $\mathrm{Tl}(5$-metrop) & $128 / \mathrm{ND}$ & $64 / \mathrm{ND}$ & $256 / N D$ & $256 / N D$ & $128 / \mathrm{ND}$ & $128 / \mathrm{ND}$ & $256 / N D$ & 64/ND \\
\hline $\mathrm{Bi}(5 \text {-metrop })_{2}\left(\mathrm{NO}_{3}\right)$ & $16 / N D$ & $8 / N D$ & 8/ND & 8/ND & 8/ND & $16 / \mathrm{ND}$ & $2 / \mathrm{ND}$ & $32 / \mathrm{ND}$ \\
\hline 5-meHtrop & $32 / 512$ & $16 / \mathrm{ND}$ & $128 / \mathrm{ND}$ & $128 / \mathrm{ND}$ & $128 / \mathrm{ND}$ & $256 / N D$ & $2 / 256$ & $32 / 512$ \\
\hline Tl(hino) & $128 / 512$ & $128 / 512$ & $128 / N D$ & $64 / \mathrm{ND}$ & $256 / N D$ & $256 / N D$ & $64 / 512$ & $32 / \mathrm{ND}$ \\
\hline $\mathrm{Pb}(\text { hino })_{2}$ & $64 / N D$ & $64 / N D$ & $128 / \mathrm{ND}$ & $256 / N D$ & $512 / \mathrm{ND}$ & $512 / N D$ & $64 / N D$ & $64 / \mathrm{ND}$ \\
\hline Hhino & $64 / 256$ & $32 / 128$ & $64 / 256$ & $128 / \mathrm{ND}$ & $256 / N D$ & $256 / N D$ & $32 / N D$ & $32 / 512$ \\
\hline
\end{tabular}

* ND: killing effect not detected in the tested range of concentrations.

Surprisingly, none of the thallium(I) complexes displayed potent antimicrobial activity. Moreover, the free 5-meHtrop ligand had high activity against E. faecalis ATCC 29212 (MIC $\left.=2 \mathrm{mg} \cdot \mathrm{mL}^{-1}\right)$, whereas the activity of the Tl(5-metrop) complex was significantly reduced (MIC $=256 \mathrm{mg} \cdot \mathrm{mL}^{-1}$ ). This suggested that the $\alpha$-hydroxycarbonyl moiety with neighboring $\mathrm{OH}$ and $\mathrm{C}=\mathrm{O}$ groups, present in the free ligand and blocked in the thallium(I) complex, played a crucial role in the antimicrobial activity of the free 5-meHtrop ligand. In addition, the two lead(II) complexes showed no significant activity against the tested microorganisms. In contrast, but in line with previous reports [60-62], the bismuth(III) complexes demonstrated significant antimicrobial activity. It was found earlier that some bismuth(III) tropolonates showed higher activity against Helicobacter pylori in the agar dilution test than the standard bismuth(III) salicylate [13]. Nevertheless, the bismuth(III) hinokitiolate complex did not demonstrate a specific antimicrobial action [7]. The mechanism of the bismuth compounds antimicrobial activity is not fully understood. Yet, it is known that they increase the permeability of the bacterial cell membrane and reduce the glycocalyx production [63,64]. All tested bismuth(III) complexes showed 2- to 5-fold larger activity than their free ligands (Table 6). In the case of S. aureus ATCC 29213, the MIC values were $8 \mathrm{mg} \cdot \mathrm{mL}^{-1}$ for the bismuth(III) complexes, and $128 \mathrm{mg} \cdot \mathrm{mL}^{-1}$ for ligands. For this very reference strain, the MIC cut-off values of the majority of the antibiotics administrated for treatment were significantly lower. However, for chloramphenicol, an antibiotic used to treat staphylococci infections, the breakpoint was $8 \mathrm{mg} \cdot \mathrm{mL}^{-1}$ as well. The same MIC value was also demonstrated by the Bi(trop) $)_{3}$ complex against $E$. coli ATCC 25922 and E. faecalis ATCC 29212 , and also by the Bi(5-metrop $)_{2}\left(\mathrm{NO}_{3}\right)$ complex against S. aureus ATCC 6538, E. coli ATCC 25922, and P. aeruginosa ATCC 9027. On the other hand, for amikacin, a broad-spectrum antibiotic to treat infections caused by Gram-negative and Gram-positive bacteria, the breakpoint against $P$. aeruginosa was $16 \mathrm{mg} \cdot \mathrm{mL}^{-1}$. Thus, the $\mathrm{Bi}(5 \text {-metrop })_{2}\left(\mathrm{NO}_{3}\right)$ complex displayed a two-times lower MIC.

Much less satisfactory were the minimum bactericidal concentration values; $\mathrm{MBC}=16 \mathrm{mg} \cdot \mathrm{mL}^{-1}$ was obtained for $\left[\mathrm{Bi}_{2}(\text { trop })_{4}\left(\mathrm{NO}_{3}\right)_{2}\right]_{\mathrm{n}}$ and $\mathrm{Bi}$ (trop $)_{3}$ complexes against E. coli ATCC 25922, S. aureus ATCC 29213, and S. aureus ATCC 6538. Moreover, the two complexes exhibited $\mathrm{MBC}=64 \mathrm{mg} \cdot \mathrm{mL}^{-1}$ against $P$. aeruginosa ATCC 27853 and $P$. aeruginosa ATCC 9027. The Bi(trop) ${ }_{3}$ complex showed a killing activity of $256 \mathrm{mg} \cdot \mathrm{mL}^{-1}$ with MBC for E. coli ATCC 8739. However, the MBC for the Tl(hino) complex was equal to $512 \mathrm{mg} \cdot \mathrm{mL}^{-1}$ against both: E. coli strains, ATCC 25922, ATCC 8739, and E. faecalis ATCC 29212, but the other thallium(I) complexes did not show a killing effect in the tested range of concentrations (Table 6).

\section{Materials and Methods}

The 5-Methyltropolone was synthesized as presented earlier [52]. All the other reagents were used as purchased from commercial sources. The IR spectra were recorded on a Thermo Scientific Nicolet iS10 FT-IR spectrometer (Thermo Fisher Scientific, Waltham, 
MA, USA) in the 4000-650 $\mathrm{cm}^{-1}$ range with $4 \mathrm{~cm}^{-1}$ resolution using a PIKE Technologies MIRacle (Madison, WI, USA) accessory equipped with ZnSe crystal designed for single reflection horizontal ATR technique. UV-vis spectra were registered with Thermo Scientific Evolution 600 (Thermo Fisher Scientific, Waltham, MA, USA) or Perkin-Elmer Lambda 35 spectrometers (Waltham, MA, USA) using methanol solutions of the studied complexes and ligands. Emission spectra and fluorescence lifetimes at room temperature were collected on a Horiba Fluorolog 3 fluorimeter (Horiba Scientific, Piscataway, NJ, USA). Excitation for fluorescence lifetime measurements was provided by Delta Diode 336 and $303 \mathrm{~nm}$ for solutions and solid states, respectively. The ${ }^{1} \mathrm{H},{ }^{13} \mathrm{C},{ }^{19} \mathrm{~F}$, and ${ }^{205} \mathrm{Tl} \mathrm{NMR}$ spectra of DMSO- $d_{6}$ solutions were recorded at $298 \mathrm{~K}$ on a Bruker AVANCE III HD 500 $\mathrm{MHz}$ spectrometer (Bruker, Billerica, MA, USA). An aqueous solution of thallium(I) nitrate $\left(1 \mathrm{~mol} \cdot \mathrm{dm}^{-3}\right)$ was used as a chemical shift reference $(0 \mathrm{ppm})$. The numbering of carbon atoms in the description of NMR signals is shown in Scheme 1.

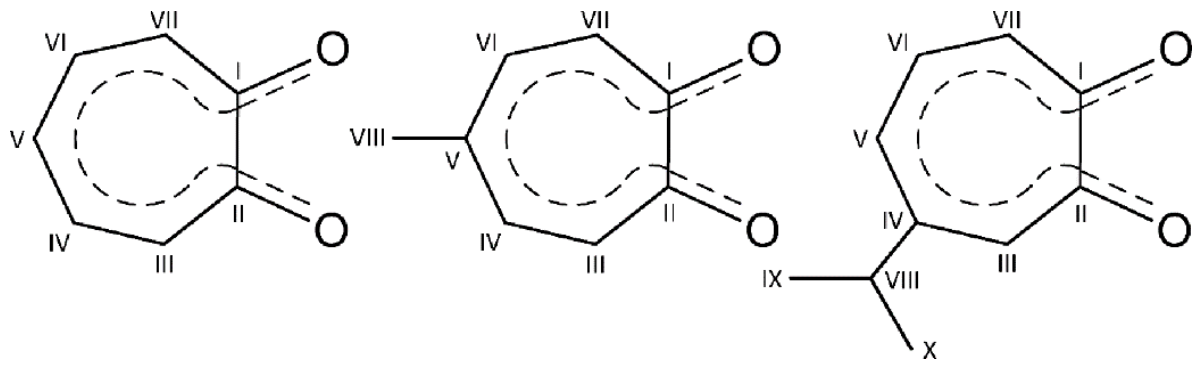

Scheme 1. Atom labeling in tropolonato-like ligands used for NMR assignments.

\subsection{Preparation of the Thallium(I) Compounds}

\subsection{1. $\mathrm{Tl}\left(\mathrm{CF}_{3} \mathrm{SO}_{3}\right)(\mathrm{Tl}(\mathrm{OTf}))$}

The thallium(I) triflate was synthesized in the reaction of metallic thallium with concentrated aqueous solution of trifluoromethanesulfonic acid, followed by evaporation of the excess of water and acid. ATR-IR (ZnSe), $v_{\max } / \mathrm{cm}^{-1}: 1217 \mathrm{vs}\left(\mathrm{SO}_{3}\right), 1160 \mathrm{~m}\left(\mathrm{CF}_{3}\right)$, $1015 \mathrm{~m}\left(\mathrm{SO}_{3}\right), 763 \mathrm{w}\left(\mathrm{CF}_{3}\right)$; assignments based on [65]. ${ }^{13} \mathrm{C}$ NMR $\left(125.79 \mathrm{MHz}, \mathrm{DMSO}-d_{6}\right)$ $\delta / \mathrm{ppm}: 120.70\left(\mathrm{CF}_{3}\right) .{ }^{19} \mathrm{~F}$ NMR $\left(470.63 \mathrm{MHz}, \mathrm{DMSO}-d_{6}\right) \delta / \mathrm{ppm}:-77.73\left(\mathrm{CF}_{3}\right)$.

\subsubsection{Co-Crystals of Thallium(I) Triflate and Tropolone-Tl(OTf)·Htrop}

The titled crystals were obtained from the methanol solution $(0.3 \mathrm{~mL})$ containing thallium(I) triflate $(0.151 \mathrm{~g}, 0.427 \mathrm{mmol})$ and tropolone $(0.052 \mathrm{~g}, 0.426 \mathrm{mmol})$ at a molar ratio of 1:1. The prepared solution was stored in a fridge until almost all of the solvent was evaporated off, giving colorless, platelet-shaped crystals. Yield: $0.190 \mathrm{~g}, 94.1 \%$ (based on Tl). Anal. Calc. for $\mathrm{C}_{8} \mathrm{H}_{6} \mathrm{~F}_{3} \mathrm{O}_{5} \mathrm{STl}$ : C, 20.20; H, 1.27; S, 6.74. Found: C, 20.21; $\mathrm{H}, 1.29$; S, 6.78\%. ATR-IR (ZnSe), $v_{\max } / \mathrm{cm}^{-1}: 3170 \mathrm{br}, 3015 \mathrm{br}, 1607 \mathrm{~m}, 1559 \mathrm{vw}, 1532 \mathrm{w}, 1484 \mathrm{~m}$, $1458 \mathrm{sh}, 1433 \mathrm{~m}, 1307 \mathrm{vw}, 1254 \mathrm{sh}, 1233 \mathrm{~s}, 1218 \mathrm{vs}, 1154 \mathrm{vs}, 1056 \mathrm{vw}, 1021 \mathrm{~m}, 960 \mathrm{w}, 932 \mathrm{vw}$, 878 w, 768 w, 759 sh, 716 w, 688 w, 669 vw. ${ }^{1} \mathrm{H}$ NMR $\left(500.20 \mathrm{MHz}\right.$, DMSO-d $\left.d_{6}\right) \delta / \mathrm{ppm}: 7.05$ (t, $\left.1 \mathrm{H}, \mathrm{H}^{\mathrm{V}}\right), 7.22\left(\mathrm{dd}, 2 \mathrm{H}, \mathrm{H}^{\mathrm{II}, \mathrm{VII}}\right), 7.41\left(\mathrm{ddd}, 2 \mathrm{H}, \mathrm{H}^{\mathrm{IV}, \mathrm{VI}}\right) .{ }^{13} \mathrm{C}$ NMR $\left(125.79 \mathrm{MHz}, \mathrm{DMSO}-d_{6}\right)$

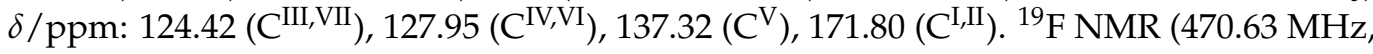
DMSO- $\left.d_{6}\right) \delta /$ ppm: $-77.73\left(\mathrm{CF}_{3}\right)$.

\subsection{3. $\mathrm{Tl}($ trop) $(\mathbf{1})$}

Thallium(I) nitrate $(0.100 \mathrm{~g}, 0.375 \mathrm{mmol})$ was dissolved in hot water $(1.0 \mathrm{~mL})$, and to this solution, tropolone $(0.045 \mathrm{~g}, 0.377 \mathrm{mmol})$ in methanol $(0.5 \mathrm{~mL})$ was added. To the resulting mixture, an aqueous ammonia solution $\left(28 \mu \mathrm{L}, 25 \%, 0.376 \mathrm{mmol} \mathrm{NH}_{3}\right)$ dissolved in methanol $(0.2 \mathrm{~mL})$ was slowly added dropwise. The whole mixture was stirred at all times. During the addition of ammonia solution, the mixture had already turned yellow, and a yellow crystalline material of $\mathbf{1}$ began to precipitate. After a few hours, this compound was isolated from the solution. Yield: $0.058 \mathrm{~g}, 47.5 \%$ (based on Tl). Anal. Calc. 
for $\mathrm{C}_{7} \mathrm{H}_{5} \mathrm{O}_{2} \mathrm{Tl}: \mathrm{C}, 25.83 ; \mathrm{H}, 1.55$. Found: $\mathrm{C}, 25.78 ; \mathrm{H}, 1.68 \%$. UV-vis (methanol), $\lambda_{\max } / \mathrm{nm}$ $\left(\varepsilon / \mathrm{M}^{-1} \cdot \mathrm{cm}^{-1}\right): 332$ (12 800), 370sh (6000), 396 (6050). ATR-IR (ZnSe), $v_{\max } / \mathrm{cm}^{-1}: 3029 \mathrm{vw}$, 3008 vw, 2986 vw, 1588 m, 1492 m, 1466 sh, 1429 sh, 1412 sh, 1389 s, 1380 sh, 1358 m, 1348 sh, 1229 sh, 1217 vs, 995 vw, 970 w, 898 vw, 877 w, 728 m, 721 sh, 679 vw. ${ }^{1} \mathrm{H}$ NMR $(500.20 \mathrm{MHz}$, DMSO- $\left.d_{6}\right) \delta /$ ppm: $6.54\left(\mathrm{dd}, 1 \mathrm{H}, \mathrm{H}^{\mathrm{V}}\right), 6.77\left(\mathrm{~d}, 2 \mathrm{H}, \mathrm{H}^{\mathrm{III}, \mathrm{VII}}\right), 7.62\left(\mathrm{dd}, 2 \mathrm{H}, \mathrm{H}^{\mathrm{IV}, \mathrm{VI}}\right) .{ }^{13} \mathrm{C}$ NMR (125.79 MHz, DMSO- $\left.d_{6}\right) \delta /$ ppm: $120.30\left(\mathrm{C}^{\mathrm{V}}\right), 124.81\left(\mathrm{C}^{\mathrm{III}, \mathrm{VII}}\right), 135.32\left(\mathrm{C}^{\mathrm{IV}, \mathrm{VI}}\right), 183.10\left(\mathrm{C}^{\mathrm{I}, \mathrm{II}}\right)$.

\subsection{4. $\mathrm{Tl}(5$-metrop) (2)}

Thallium(I) triflate $(0.039 \mathrm{~g}, 0.110 \mathrm{mmol})$ and 5-methyltropolone $(0.015 \mathrm{~g}, 0.110 \mathrm{mmol})$ were dissolved in methanol $(1.0 \mathrm{~mL})$. Then, a solution of ammonia $\left(8.3 \mu \mathrm{L}, 25 \%\right.$ in $\left.\mathrm{H}_{2} \mathrm{O}\right)$ in methanol $(0.2 \mathrm{~mL})$ was slowly added to the stirred mixture. During the addition of the ammonia solution, lemon-yellow crystals were precipitated. Yield: $0.012 \mathrm{~g}, 32.4 \%$ (based on Tl). Anal. Calc. for $\mathrm{C}_{8} \mathrm{H}_{7} \mathrm{O}_{2} \mathrm{Tl}$ : C, 28.30; H, 2.08. Found: C, 28.30; $\mathrm{H}, 2.10 \%$. UV-vis (methanol), $\lambda_{\max } / \mathrm{nm}\left(\varepsilon / \mathrm{M}^{-1} \cdot \mathrm{cm}^{-1}\right): 332$ (8330), 372sh (4150), 401 (2100). ATR-IR (ZnSe), $v_{\max } / \mathrm{cm}^{-1}: 3015 \mathrm{vw}, 2915 \mathrm{vw}, 1605 \mathrm{w}, 1594 \mathrm{sh}, 1546 \mathrm{vw}, 1508 \mathrm{~m}, 1496 \mathrm{sh}, 1453 \mathrm{sh}, 1425 \mathrm{~s}$, 1396 sh, 1379 w, 1363 m, 1338 vs, 1238 m, 1220 sh, 1124 w, 1041 vw, 992 vw, 957 vw, $895 \mathrm{vw}, 872$ vw, $849 \mathrm{vw}, 824 \mathrm{~m}, 765 \mathrm{w}, 738 \mathrm{~m}, 668 \mathrm{vw} .{ }^{1} \mathrm{H}$ NMR (500.20 MHz, DMSO-d $)$ $\delta /$ ppm: $2.28\left(\mathrm{~s}, 3 \mathrm{H}, \mathrm{H}^{\mathrm{VIII}}\right), 6.75\left(\mathrm{~d}, 2 \mathrm{H}, \mathrm{H}^{\mathrm{III}}, \mathrm{VII}\right), 7.10\left(\mathrm{~d}, 2 \mathrm{H}, \mathrm{H}^{\mathrm{IV}, \mathrm{VI}}\right) .{ }^{13} \mathrm{C}$ NMR $(125.79 \mathrm{MHz}$, DMSO- $\left.d_{6}\right) \delta$ /ppm: $24.31\left(\mathrm{C}^{\mathrm{VIII}}\right), 125.44\left(\mathrm{C}^{\mathrm{III}, \mathrm{VII}}\right), 129.68\left(\mathrm{C}^{\mathrm{V}}\right), 136.34\left(\mathrm{C}^{\mathrm{IV}, \mathrm{VI}}\right), 182.14\left(\mathrm{C}^{\mathrm{I}, \mathrm{II}}\right)$.

\subsubsection{Tl(hino) (3)}

Thallium(I) nitrate $(0.050 \mathrm{~g}, 0.188 \mathrm{mmol})$ was dissolved in hot water $(0.4 \mathrm{~mL})$ and mixed with a solution of hinokitiol $(0.031 \mathrm{~g}, 0.189 \mathrm{mmol})$ in methanol $(1.0 \mathrm{~mL})$. Then, an ammonia solution $\left(29 \mu \mathrm{L}, 25 \%\right.$ in $\left.\mathrm{H}_{2} \mathrm{O}, \sim 0.188 \mathrm{mmol}\right)$ dissolved in methanol $(0.1 \mathrm{~mL})$ was slowly added, and the whole mixture was stirred and slightly heated for about $2 \mathrm{~h}$. After the addition of ammonia, a yellow compound began to precipitate. Then, the solution was stored at room temperature, and light-yellow needlelike crystals of $\mathbf{3}$ were separated after a few days. Yield: $0.054 \mathrm{~g}, 78.3 \%$ (based on Tl). Anal. Calc. for $\mathrm{C}_{10} \mathrm{H}_{11} \mathrm{O}_{2} \mathrm{Tl}$ : C, 32.68; $\mathrm{H}$, 3.02. Found: C, 32.52; H, 2.87\%. UV-vis (methanol), $\lambda_{\max } / \mathrm{nm}\left(\varepsilon / \mathrm{M}^{-1} \cdot \mathrm{cm}^{-1}\right): 332(9600)$, 365sh (5450), 391 (3500). ATR-IR (ZnSe), $v_{\max } / \mathrm{cm}^{-1}$ : $3025 \mathrm{vw}, \mathrm{br}, 2958 \mathrm{w}, 2929$ vw, br, 2885 vw, 2865 vw, 1581 m, 1489 m, 1450 m, 1416 sh, 1392 s, 1381 sh, 1358 s, 1318 vw, 1308 sh, $1291 \mathrm{~m}, 1230 \mathrm{vs}, 1187 \mathrm{vw}, 1125 \mathrm{vw}, 1102 \mathrm{vw}, 1189 \mathrm{vw}, 1064 \mathrm{vw}, 1045 \mathrm{vw}, 1015 \mathrm{vw}, 957 \mathrm{w}$, $905 \mathrm{vw}, 895 \mathrm{vw}, 889 \mathrm{vw}, 876 \mathrm{sh}, 807 \mathrm{w}, 768 \mathrm{w}, 751 \mathrm{vw}, 747 \mathrm{vw}, \mathrm{sh}, 721 \mathrm{w}, 669 \mathrm{vw} .{ }^{1} \mathrm{H} \mathrm{NMR}$ (500.20 MHz, DMSO- $\left.d_{6}\right) \delta /$ ppm: $1.18\left(\mathrm{~d}, 6 \mathrm{H}, \mathrm{H}^{\mathrm{IX}, \mathrm{X}}\right), 2.74\left(\mathrm{~m}, 1 \mathrm{H}, \mathrm{H}^{\mathrm{VIII}}\right), 6.52\left(\mathrm{dd}, 1 \mathrm{H}, \mathrm{H}^{\mathrm{V}}\right)$, $6.66\left(\mathrm{~d}, 1 \mathrm{H}, \mathrm{H}^{\mathrm{VII}}\right), 6.78\left(\mathrm{~d}, 1 \mathrm{H}, \mathrm{H}^{\mathrm{III}}\right), 7.12\left(\mathrm{dd}, 1 \mathrm{H}, \mathrm{H}^{\mathrm{VI}}\right) .{ }^{13} \mathrm{C}$ NMR $\left(125.79 \mathrm{MHz}, \mathrm{DMSO}-d_{6}\right)$

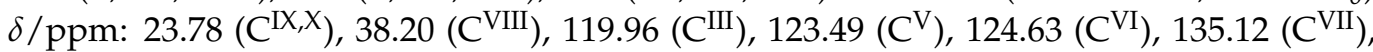
$156.14\left(\mathrm{C}^{\mathrm{IV}}\right), 181.98\left(\mathrm{C}^{\mathrm{I}}\right), 186.66\left(\mathrm{C}^{\mathrm{II}}\right)$.

\subsubsection{Tl@[Tl(hino) $\left.]_{6}\right\}(\mathrm{OTf})(4)$}

The titled compound was obtained from methanol solution $(1.0 \mathrm{~mL})$ in a similar way as for 3 using the following amounts of reagents: thallium(I) triflate $(0.050 \mathrm{~g}, 0.141 \mathrm{mmol})$, hinokitiol (0.023 g, $0.140 \mathrm{mmol})$, and ammonia $\left(21 \mu \mathrm{L}, 25 \%\right.$ in $\left.\mathrm{H}_{2} \mathrm{O}, \sim 0.136 \mathrm{mmol}\right)$. The volume of the reaction mixture was reduced under warming to about half of its starting volume. Yellow platelike crystals were separated from this solution after storing it for a few days at room temperature. Yield: $0.018 \mathrm{~g}, 34.6 \%$ (based on $\mathrm{Tl}$ ). Anal. Calc. for $\mathrm{C}_{61} \mathrm{H}_{66} \mathrm{~F}_{3} \mathrm{O}_{15} \mathrm{STl}_{7}$ : C, 28.63; H, 2.60; S, 1.25. Found: C, 28.67; H, 2.56; S, 1.27\%. UV-vis (methanol), $\lambda_{\max } / \mathrm{nm}\left(\varepsilon / \mathrm{M}^{-1} \cdot \mathrm{cm}^{-1}\right.$, based on the concentration of Tl(hino)): 332 (8571), 365sh (4151), 391 (4087). ATR-IR (ZnSe), $v_{\max } / \mathrm{cm}^{-1}$ : $2964 \mathrm{vw}, \mathrm{br}, 2878 \mathrm{vw}, 1584 \mathrm{w}, 1574 \mathrm{sh}$, 1559 sh, 1494 m, 1455 sh, 1446 m, 1438 sh, 1404 s, 1383 m, 1357 m, 1337 m, 1315 w, 1275 s, 1238 vs, 1185 vw, 1143 m, 1109 vw, 1092 vw, 1033 w, 965 w, 908 vw, 889 vw, 814 w, 766 w, $755 \mathrm{w}, 721 \mathrm{sh}, 713 \mathrm{w}, 669$ vw. ${ }^{1} \mathrm{H}$ NMR $\left(500.20 \mathrm{MHz}, \mathrm{DMSO}-d_{6}\right) \delta / \mathrm{ppm}: 1.18\left(\mathrm{~d}, 6 \mathrm{H}, \mathrm{H}^{\mathrm{IX}, \mathrm{X}}\right)$, $2.74\left(\mathrm{~m}, 1 \mathrm{H}, \mathrm{H}^{\mathrm{VIII}}\right), 6.52\left(\mathrm{dd}, 1 \mathrm{H}, \mathrm{H}^{\mathrm{V}}\right), 6.65\left(\mathrm{~d}, 1 \mathrm{H}, \mathrm{H}^{\mathrm{VII}}\right), 6.78\left(\mathrm{~d}, 1 \mathrm{H}, \mathrm{H}^{\mathrm{III}}\right), 7.12(\mathrm{dd}, 1 \mathrm{H}$, $\left.\mathrm{H}^{\mathrm{VI}}\right) .{ }^{13} \mathrm{C}$ NMR (125.79 MHz, DMSO-d 6 ) $\delta / \mathrm{ppm}: 23.78\left(\mathrm{C}^{\mathrm{IX}, \mathrm{X}}\right), 38.20\left(\mathrm{C}^{\mathrm{VIII}}\right), 119.91\left(\mathrm{C}^{\mathrm{III}}\right)$, 
$123.51\left(\mathrm{C}^{\mathrm{V}}\right), 124.65\left(\mathrm{C}^{\mathrm{VI}}\right), 135.11\left(\mathrm{C}^{\mathrm{VII}}\right), 156.13\left(\mathrm{C}^{\mathrm{IV}}\right), 182.10\left(\mathrm{C}^{\mathrm{I}}\right), 186.66\left(\mathrm{C}^{\mathrm{II}}\right) .{ }^{19} \mathrm{~F}$ NMR (470.63 MHz, DMSO-d $\left.d_{6}\right) \delta /$ ppm: $-77.74\left(\mathrm{CF}_{3}\right)$.

\subsection{Single-Crystal X-ray Diffraction}

X-ray diffraction data for the obtained crystals were collected at $100 \mathrm{~K}$ on a Rigaku SuperNova (dual source) diffractometer equipped with an Eos CCD detector using the mirror-monochromated Mo K $\alpha$ or $\mathrm{Cu} K \alpha$ radiations $(\lambda=0.71073$ or $1.54184 \AA)$ from a microfocus Mova or Nova X-ray sources, respectively. A suitable single crystal was mounted on a nylon loop using cryoprotectant oil (Paratone-N). The majority of the solid Tl(OTf) compound was noncrystalline, giving no reflections in the course of pre-experiment during the X-ray analysis. However, it succeeded in finding the more ordered material suitable for scXRD measurement. Crystallographic parameters and refinement details for all studied compounds are given in Table S1. Data collection and reduction were performed using CrysAlis PRO software. For the crystals, the empirical absorption correction using spherical harmonics, implemented in the SCALE3 ABSPACK scaling algorithm, was introduced. The crystal structures were solved by the direct method and refined by the full-matrix least-squares method on $F^{2}$ data. All nonhydrogen atoms (except for O3, O4, O5, O6, and $\mathrm{C} 1$ atoms in $\mathrm{Tl}(\mathrm{OTf})$ ) were refined with anisotropic atomic displacement parameters. All $\mathrm{H}$ atoms bonded to $\mathrm{C}$ atoms were placed in calculated positions with $\mathrm{C}-\mathrm{H}=0.95$ (aromatic), 0.98 (methyl), or $1.00 \AA$ (methine) and refined isotropically using a riding model with $U_{\text {iso }}(\mathrm{H})=1.5 U_{\text {eq }}(\mathrm{C})$ for the methyl $\mathrm{H}$ atoms and $1.2 U_{\text {eq }}(\mathrm{C})$ for the remaining $\mathrm{H}$ atoms. The $\mathrm{H}$ atom of the $\mathrm{OH}$ group in $\mathrm{Tl}(\mathrm{OTf}) \cdot \mathrm{Htrop}$ was located in a difference map, and its position and isotropic thermal parameter $U_{\text {iso }}$ were freely refined. All calculations were performed with the SHELXTL program package [66] integrated with the OLEX2 crystallographic software [67]. The MERCURY program [68] was applied for the structural graphics.

\subsection{Antimicrobial Activity}

The in vitro antimicrobial activity of ligands and complexes dissolved in DMSO was determined according to ISO 20776-1 [69]. The minimum inhibitory concentrations (MICs) and minimum bactericidal/fungicidal concentrations (MBCs/MFCs) were tested for reference microorganisms obtained from the ATCC Culture Collection [70]: E. coli ATCC 8739, E. coli ATCC 25922, P. aeruginosa ATCC 9027, P. aeruginosa ATCC 27853, S. aureus ATCC 6538, S. aureus ATCC 29213, E. faecalis ATCC 29212, and C. albicans ATCC 10232. The procedure consisted of the preparation of 2-fold dilutions of the tested compounds in liquid growth medium dispensed into a 96-well microtiter plate. Serial dilutions were carried out from 512 to $0.5 \mathrm{mg} \cdot \mathrm{mL}^{-1}$ and inoculated with standardized microbial suspension (adjusted to $0.5 \mathrm{McF}$ arland scale) prepared in the same media in a total volume of $200 \mathrm{~mL}$ per well. Culture plates were incubated at $35^{\circ} \mathrm{C}$ for $18 \mathrm{~h}$. The lowest concentration of compound inhibiting visible bacterial/fungal growth was referred to as the MIC, and that causing inoculum death was reported as the MBC/MFC.

\section{Conclusions}

Thallium(I) triflate (Tl(OTf)) was synthesized in the reaction of the concentrated aqueous solution of trifluoromethanesulfonic acid with metallic thallium. Co-crystals of thallium(I) triflate and tropolone (Tl(OTf).Htrop) were obtained from a mixture of both compounds at a 1:1 molar ratio. Reactions of tropolone (Htrop) and 5-methyltropolone (5-meHtrop) with thallium(I) triflate or nitrate(V) in methanol solution after addition of an equimolar amount of ammonia led to the formation of the simple chelates: $\mathrm{Tl}($ trop) (1) and Tl(5-metrop) (2). In the case of 4-isopropyltropolone (hinokitiol, Hhino), a similar process gave the simple $\mathrm{Tl}(\mathrm{hino})$ complex (3) when using thallium(I) nitrate(V) and the more complex compound $\left\{\mathrm{Tl} @[\mathrm{Tl}(\mathrm{hino})]_{6}\right\}(\mathrm{OTf})$ (4) for the thallium(I) triflate salt. The crystal structures of thallium(I) triflate, its co-crystal with tropolone, and complexes 1-4 were determined by means of single-crystal X-ray diffraction and characterized by FT-IR, NMR $\left({ }^{1} \mathrm{H},{ }^{13} \mathrm{C},{ }^{19} \mathrm{~F}\right.$, and $\left.{ }^{205} \mathrm{Tl}\right), \mathrm{UV}$-vis, and luminescence techniques. Antimicrobial activity 
of thallium(I) complexes was tested and compared with free ligands and selected analogous lead(II) and bismuth(III) compounds. None of the thallium(I) complexes showed significant antimicrobial activity. Of the other compounds tested, only the bismuth(III) complexes presented potentially interesting activity, two to five times larger than their free ligands.

Supplementary Materials: The following are available online, Table S1: Crystal data and structure refinement details for studied thallium(I) compounds; Figure S1: ATR-FTIR of Tl(OTf); Figure S2: ATR-FTIR of Tl(OTf)·Htrop adduct; Figure S3: ATR-FTIR of Htrop; Figure S4: ATR-FTIR of Tl(trop) (1); Figure S5: ATR-FTIR of 5-meHtrop; Figure S6: ATR-FTIR of Tl(5-metrop) (2); Figure S7: ATR-FTIR of Hhino; Figure S8: ATR-FTIR of Tl(hino) (3); Figure S9: ATR-FTIR of $\left.\{\text { Tl@[Tl(hino) }]_{6}\right\}(\mathrm{OTf})(4)$; Figure S10: Experimental UV-vis absorption spectra of the studied thallium(I) complexes (red lines) in comparison with the respective ligand (black lines) measured in $\mathrm{MeOH}$ solutions; Figure S11: Excitation and emission spectra for complexes 2-5 in methanol (left) and the solid state (right); Figure S12: ${ }^{13} \mathrm{C}$ NMR spectrum of Tl(OTf); Figure S13: (a) ${ }^{1} \mathrm{H}$ NMR, (b) ${ }^{13} \mathrm{C}$ NMR, and (c) ${ }^{19} \mathrm{~F}$ NMR spectra of Tl(OTf).Htrop adduct; Figure S14: (a) ${ }^{1} \mathrm{H}$ NMR and (b) ${ }^{13} \mathrm{C}$ NMR spectra of Tl(trop) (1); Figure S15: (a) ${ }^{1} \mathrm{H}$ NMR and (b) ${ }^{13} \mathrm{C}$ NMR spectra of Tl(5-metrop) (2); Figure S16: (a) ${ }^{1} \mathrm{H}$ NMR and (b) ${ }^{13} \mathrm{C}$ NMR spectra of Tl(hino) (3); Figure S17: (a) ${ }^{1} \mathrm{H}$ NMR, (b) ${ }^{13} \mathrm{C}$ NMR, and (c) ${ }^{19} \mathrm{~F}$ NMR spectra of $\left\{\mathrm{Tl}\left[\mathrm{Tl}(\text { hino) }]_{6}\right\}\right.$ (OTf) (4); Figure S18: ${ }^{205} \mathrm{Tl}$ NMR spectra of studied thallium(I) compounds.

Author Contributions: Conceptualization and supervision, K.L.; investigation, K.L., M.L., M.B., K.W., A.Z., and A.B.; writing—original draft preparation, K.L., A.B., and M.B.; writing-review and editing, K.L. and J.C.D. All authors have read and agreed to the published version of the manuscript.

Funding: This work was supported by the Institute of Nuclear Chemistry and Technology statutory research. The National Medicines Institute financed the antimicrobial activity studies.

Institutional Review Board Statement: Not applicable.

Informed Consent Statement: Not applicable.

Data Availability Statement: CCDC 2126510-2126515 contain the supplementary crystallographic data for this paper. These data can be obtained free of charge from the Cambridge Crystallographic Data Center at http:/ / www.ccdc.cam.ac.uk/data_request/cif (accessed on 6 December 2021).

Acknowledgments: The authors sincerely thank Kanji Kubo (Hokkai-Gakuen University, Sapporo, Japan) for supplying the 5-methyltropolone.

Conflicts of Interest: The authors declare no conflict of interest.

Sample Availability: Samples of the compounds in this article are not available from the authors.

\section{References}

1. Ouyang, W.-C.; Liao, Y.-W.; Chen, P.-N.; Lu, K.-H.; Yu, C.-C.; Hsieh, P.-L. Hinokitiol suppresses cancer stemness and oncogenicity in glioma stem cells by Nrf2 regulation. Cancer Chemother. Pharmacol. 2017, 80, 411-419. [CrossRef]

2. Saniewski, M.; Horbowicz, M.; Kanlayanarat, S. The biological activities of troponoids and their use in agriculture. J. Hort. Res. 2014, 22, 5-19. [CrossRef]

3. Shih, Y.-H.; Chang, K.-W.; Hsia, S.-M.; Yu, C.-C.; Fuh, L.-J.; Chi, T.-Y.; Shieh, T.-M. In vitro antimicrobial and anticancer potential of hinokitiol against oral pathogens and oral cancer cell lines. Microbiol. Res. 2013, 168, 254-262. [CrossRef]

4. Morita, Y.; Matsumura, E.; Okabe, T.; Shibata, M.; Sugiura, M.; Ohe, T.; Tsujibo, H.; Ishida, N.; Inamori, Y. Biological activity of tropolone. Biol. Pharm. Bull. 2003, 26, 1487-1490. [CrossRef]

5. Koufaki, M.; Theodorou, E.; Alexi, X.; Nikoloudaki, F.; Alexis, M.N. Synthesis of tropolone derivatives and evaluation of their in vitro neuroprotective activity. Eur. J. Med. Chem. 2010, 45, 1107-1112. [CrossRef]

6. Baya, M.; Soulounganga, P.; Gelhaye, E.; Gérardin, P. Fungicidal activity of $\beta$-thujaplicin analogues. Pest. Manag. Sci. 2001, 57, 833-838. [CrossRef]

7. $\quad$ Nomiya, K.; Onodera, K.; Tsukagoshi, K.; Shimada, K.; Yoshizawa, A.; Itoyanagi, T.; Sugie, A.; Tsuruta, S.; Sato, R.; Kasuga, N.C. Syntheses, structures and antimicrobial activities of various metal complexes of hinokitiol. Inorg. Chim. Acta 2009, $362,43-55$. [CrossRef]

8. Barret, M.C.; Mahon, M.F.; Molloy, K.C.; Steed, J.W.; Wright, P. Synthesis and Structural Characterization of Tin(II) and Zinc(II) Derivatives of Cyclic $\alpha$-Hydroxyketones, Including the Structures of Sn(maltol $)_{2}, \mathrm{Sn}$ (tropolone) $)_{2}$, Zn(tropolone) $)_{2}$, and $\mathrm{Zn}(\text { hinokitiol) })_{2}$. Inorg. Chem. 2001, 40, 4384-4388. [CrossRef]

9. Gilbard, J.P.; Douyon, Y.; Huson, R.B. Time-kill assay results for a linalool-hinokitiol-based eyelid cleanser for lid hygiene. Cornea 2010, 29, 559-563. [CrossRef] 
10. Nagao, Y.; Sata, M. Effect of oral care gel on the quality of life for oral lichen planus in patients with chronic HCV infection. Virol. J. 2011, 8, 348. [CrossRef] [PubMed]

11. Muetterties, E.L.; Wright, C.M. Chelate Chemistry. I. Tropolone and Aminotroponimine Derivatives of the Main-Group Elements. J. Am. Chem. Soc. 1964, 86, 5132-5137. [CrossRef]

12. Muetterties, E.L.; Roesky, H.; Wright, C.M. Chelate Chemistry. V. Metal Chelates Based on Tropolone and Its Derivatives. J. Am. Chem. Soc. 1966, 88, 4856-4861. [CrossRef]

13. Diemer, R.; Keppler, B.K.; Dittes, U.; Nuber, B.; Seifried, V.; Opferkuch, W. Preparation and Characterization of Biologically Active Bismuth(III) Tropolonato Complexes. Chem. Ber. 1995, 128, 335-342. [CrossRef]

14. Lyczko, K.; Starosta, W.; Persson, I. Influence of $\mathrm{pH}$ and Counteranion on the Structure of Tropolonato-Lead(II) Complexes: Structural and Infrared Characterization of Formed Lead Compounds. Inorg. Chem. 2007, 46, 4402-4410. [CrossRef]

15. Lyczko, K.; Lyczko, M.; Wozniak, K.; Stachowicz, M.; Oziminski, W.P.; Kubo, K. Influence of pH and type of counterion on the formation of bismuth(III) complexes with tropolonato and 5-methyltropolonato ligands: Synthesis, structure, spectroscopic characterization and calculation studies. Inorg. Chim. Acta 2015, 436, 57-68. [CrossRef]

16. Lyczko, K. Tropolone as anionic and neutral ligand in lead(II) and bismuth(III) complexes: Synthesis, structure, characterization and computational studies. J. Mol. Struct. 2017, 1127, 549-556. [CrossRef]

17. Lyczko, K.; Lyczko, M.; Starosta, W. Catena-Poly[( $\mu_{3}-2$-hydroxy-4-isopropylcyclohepta-2,4,6-trien-1-onato $)\left(\mu_{2}-2\right.$-hydroxy- 4isopropylcyclohepta-2,4,6-trien-1-onato)lead(II)]. Acta Crystallogr. E 2010, 66, 1395-1396. [CrossRef]

18. Chow, Y.M.; Britton, D. The Crystal Structures of Dimethylthallium Acetate, Tropolonate, Acetylacetonate, and Dibenzoylmethide. Acta Cryst. B 1975, 31, 1929-1934. [CrossRef]

19. Griffin, R.T.; Henrick, K.; Matthews, R.W. Crystal Structures of Diethyldithiocarbamatodiphenylthallium(III) and DiphenyltropolonatothaIium(III). J. Chem. Soc. Dalton Trans. 1980, 1550-1555. [CrossRef]

20. Curtis, S.; Lottes, B.; Robertson, D.; Lindeman, S.V.; Gerasimchuk, N. Search for the shortest intermetallic Tl-Tl contacts: Synthesis and characterization of Thallium(I) coordination polymers with several mono- and bis-cyanoximes. Inorg. Chim. Acta 2020, 508, 119597. [CrossRef]

21. Castillo, R.; Cisterna, J.; Brito, I.; Conejeros, S.; Llanos, J. Structure and Properties of $\left(\mathrm{CH}_{3} \mathrm{NH}_{3}\right)_{3} \mathrm{Tl}_{2} \mathrm{Cl}$ : : A Thallium-Based Hybrid Perovskite-Like Compound. Inorg. Chem. 2020, 59, 9471-9475. [CrossRef]

22. Kianimehr, A.; Akhbari, K.; White, J.; Phuruangrat, A. Sonochemical synthesis, crystal structure and thermal behavior of a new thallium(I) supramolecular polymer with hydrogen and bromine-oxygen halogen bonds. Inorg. Chem. Comm. 2020, 115, 107864. [CrossRef]

23. Golovnev, N.N.; Molokeev, M.S.; Lesnikov, M.K. Three isomers in a (hydrogen L-Cysteinato)-thallium(I): Crystal structure, spectroscopic and thermal properties. Polyhedron 2019, 173, 114141. [CrossRef]

24. Lavrentyev, A.A.; Gabrelian, B.V.; Vu, T.V.; Ananchenko, L.N.; Myronchuk, G.L.; Parasyuk, O.V.; Tkach, V.A.; Kopylova, K.I.; Khyzhun, O.Y. Electronic and optical properties of quaternary sulfide $\mathrm{Tl}_{2} \mathrm{HgSnS}$, a promising optoelectronic semiconductor: A combined experimental and theoretical study. Opt. Mater. 2019, 92, 294-302. [CrossRef]

25. Yusefi, S.; Akhbari, K.; White, J.; Phuruangrat, A. Sonochemical synthesis of a two-dimensional supramolecular polymer with nanoporous morphology, linear thallophilic and covalent hydrogen-bonding interactions. Appl. Organomet. Chem. 2020, 33 , e4747. [CrossRef]

26. Seifert, T.P.; Knoefel, N.D.; Feuerstein, T.J.; Reiter, K.; Lebedkin, S.; Gamer, M.T.; Boukis, A.C.; Weigend, F.; Kappes, M.M.; Roesky, P.W. Size Matters: From Two-Dimensional Au(I)-Tl(I) Metallopolymers to Molecular Complexes by Simple Variation of the Steric Demand. Chem. Eur. J. 2019, 25, 3799-3808. [CrossRef] [PubMed]

27. Kahrs, C.; Schmidtmann, M.; Wickleder, M.S.; Christoffers, J. Carboxylate Groups in a 90 Arrangement: 1,3-Allenedicarboxylic Acid and Its Alkali Metal and Thallium(I) Coordination Compounds. Eur. J. Inorg. Chem. 2019, 22, 2781-2787. [CrossRef]

28. Boyle, T.J.; Perales, D.; Rimsza, J.M.; Alam, T.M.; Boye, D.M.; Sears, J.M.; Greathouse, J.A.; Kemp, R.A. Synthesis and characterization of thallium-salen derivatives for use as underground fluid flow tracers. Dalton Trans. 2018, 47, 4162-4174. [CrossRef]

29. Paziresh, S.; Sicilia, V.; Ara, I.; Martín, A.; Fuertes, S. The Influence of Cyclometalated Ligand Motifs on the Solid-State Assemblies and Luminescent Properties of Pt(II)-Tl(I) Complexes. Organometallics 2019, 38, 3804-3815. [CrossRef]

30. Bai, W.; Zhang, J.-X.; Fan, T.; Tse, S.K.S.; Shou, W.; Sung, H.H.Y.; Williams, I.D.; Lin, Z.; Jia, G. Syntheses and Structures of Ruthenium Complexes Containing a Ru-H-Tl Three-Center-Two-Electron Bond. Angew. Chem. 2018, 57, 12874-12879. [CrossRef] [PubMed]

31. Fuertes, S.; Chueca, A.J.; Martín, A.; Sicilia, V. Pt 2 Tl Building Blocks for Two-Dimensional Extended Solids: Synthesis, Crystal Structures, and Luminescence. Cryst. Growth Des. 2017, 17, 4336-4346. [CrossRef]

32. Donamaría, R.; Lippolis, V.; López-de-Luzuriaga, J.M.; Monge, M.; Nieddu, M.; Elena Olmos, M. Metallophilic Au(I) … M(I) interactions $(\mathrm{M}=\mathrm{Tl}, \mathrm{Ag})$ in heteronuclear complexes with 1,4,7-triazacyclononane: Structural features and optical properties. Dalton Trans. 2020, 49, 10983-10993. [CrossRef] [PubMed]

33. Kargar, H.; Ardakani, A.A.; Tahir, M.N.; Ashfaq, M.; Munawar, K.S. Synthesis, spectral characterization, crystal structure determination and antimicrobial activity of $\mathrm{Ni}(\mathrm{II}), \mathrm{Cu}(\mathrm{II})$ and $\mathrm{Zn}(\mathrm{II})$ complexes with the Schiff base ligand derived from 3,5-dibromosalicylaldehyde. J. Mol. Struct. 2021, 1229, 129842. [CrossRef]

34. Bisceglie, F.; Bacci, C.; Vismarra, A.; Barilli, E.; Pioli, M.; Orsoni, N.; Pelosi, G. Antibacterial activity of metal complexes based on cinnamaldehyde thiosemicarbazone analogues. J. Inorg. Biochem. 2020, 203, 110888. [CrossRef] [PubMed] 
35. Stephens, L.J.; Munuganti, S.; Duffin, R.N.; Werrett, M.V.; Andrews, P.C. Is Bismuth Really the "Green" Metal? Exploring the Antimicrobial Activity and Cytotoxicity of Organobismuth Thiolate Complexes. Inorg. Chem. 2020, 59, 3494-3508. [CrossRef] [PubMed]

36. Sovari, S.N.; Zobi, F. Recent Studies on the Antimicrobial Activity of Transition Metal Complexes of Groups 6-12. Chemistry 2020, 2, 418-452. [CrossRef]

37. Mantina, M.; Chamberlin, A.C.; Valero, R.; Cramer, C.J.; Truhlar, D.G. Consistent van der Waals Radii for the Whole Main Group. J. Phys. Chem. A 2009, 113, 5806-5812. [CrossRef]

38. Shimanouchi, H.; Sasada, Y. The crystal and molecular structure of tropolone. Acta Crystallogr. B 1973, 29, 81-90. [CrossRef]

39. Fox, B.J.; Millard, M.D.; DiPasquale, A.G.; Rheingold, A.L.; Figueroa, J.S. Thallium(I) as a Coordination Site Protection Agent: Preparation of an Isolable Zero-Valent Nickel Tris-Isocyanide. Angew. Chem. 2009, 48, 3473-3477. [CrossRef] [PubMed]

40. Labios, L.A.; Millard, M.D.; Rheingold, A.L.; Figueroa, J.S. Bond Activation, Substrate Addition and Catalysis by an Isolable Two-Coordinate Pd(0) Bis-Isocyanide Monomer. J. Am. Chem. Soc. 2009, 131, 11318-11319. [CrossRef] [PubMed]

41. Emerich, B.M.; Moore, C.E.; Fox, B.J.; Rheingold, A.L.; Figueroa, J.S. Protecting-Group-Free Access to a Three-Coordinate Nickel(0) Tris-isocyanide. Organometallics 2011, 30, 2598-2608. [CrossRef]

42. Barnett, B.R.; Moore, C.E.; Chandrasekaran, P.; Sproules, S.; Rheingold, A.L.; DeBeer, S.; Figueroa, J.S. Metal-only Lewis pairs between group 10 metals and $\mathrm{Tl}(\mathrm{I})$ or $\mathrm{Ag}(\mathrm{I})$ : Insights into the electronic consequences of Z-type ligand binding. Chem. Sci. 2015, 6 , 7169-7178. [CrossRef] [PubMed]

43. Howarth, O.W.; Nelson, J.; McKee, V. Steric constraint generating large through-space ${ }^{1} \mathrm{H}_{-}{ }^{203,205} \mathrm{Tl}$ coupling in a dithallium(I) cryptate. Chem. Commun. 2000, 1, 21-22. [CrossRef]

44. Johnson, M.J.A.; Gantzel, P.K.; Kubiak, C.P. In Search of the Elusive Open-Faced Triangulo Nickel Cluster: Insertion of Thallium(I) into a $\mu_{3}$-I Capping Ligand. Organometallics 2002, 21, 3831-3832. [CrossRef]

45. Nakai, H.; Tang, Y.; Gantzel, P.; Meyer, K. A new entry to N-heterocyclic carbene chemistry: Synthesis and characterisation of a triscarbene complex of thallium(I). Chem. Commun. 2003, 1, 24-25. [CrossRef] [PubMed]

46. Devic, T.; Batail, P.; Fourmigue, M.; Avarvari, N. Unexpected Reactivity of $\mathrm{PdCl}_{2}$ and $\mathrm{PtCl}_{2}$ Complexes of the Unsaturated Diphosphine $o-\mathrm{Me}_{2} \mathrm{TTF}\left(\mathrm{PPh}_{2}\right)_{2}$ toward Chloride Abstraction with Thallium Triflate. Inorg. Chem. 2004, 43, 3136-3141. [CrossRef]

47. Willans, C.E.; Fish, C.; Green, M.; Kilby, R.J.; Lynam, J.M.; Russell, C.A.; Whitwood, A.C. Nucleophilic substitution reactions of the tricyclic triphosphorus cage $\mathrm{P}_{3}\left(\mathrm{CBu}^{\mathrm{t}}\right)_{2}$ : A novel route to polyphosphorus phosphenium complexes. Dalton Trans. 2008, 26, 3422-3428. [CrossRef] [PubMed]

48. Berthet, J.-C.; Siffredi, G.; Thuery, P.; Ephritikhine, M. Synthesis and crystal structure of pentavalent uranyl complexes. The remarkable stability of $\mathrm{UO}_{2} \mathrm{X}\left(\mathrm{X}=\mathrm{I}, \mathrm{SO}_{3} \mathrm{CF}_{3}\right)$ in non-aqueous solutions. Dalton Trans. 2009, 18, 3478-3494. [CrossRef] [PubMed]

49. Vicente, J.; Shenoy, R.V.; Martinez-Viviente, E.; Jones, P.G. Synthesis of $\mathrm{Pd}_{3} \mathrm{Tl}$ and $\mathrm{Pd}_{6} \mathrm{Tl}_{2}$ Complexes Based on a Trinuclear Aryl-Palladium(II) Complex Acting as a Metallaligand Toward Thallium(I) Through Tl-Arene and Tl-I Bonds. Inorg. Chem. 2011, 50, 7189-7194. [CrossRef] [PubMed]

50. Jurca, T.; Korobkov, I.; Gorelsky, S.I.; Richeson, D.S. Noncovalent Interactions of Metal Cations and Arenes Probed with Thallium(I) Complexes. Inorg. Chem. 2013, 52, 5749-5756. [CrossRef] [PubMed]

51. Roy, M.M.D.; Lummis, P.A.; Ferguson, M.J.; McDonald, R.; Rivard, E. Accessing Low-Valent Inorganic Cations by Using an Extremely Bulky N-Heterocyclic Carbene. Chem. Eur. J. 2017, 23, 11249-11252. [CrossRef] [PubMed]

52. Kubo, K.; Matsumoto, T.; Mori, A. 5-Methyltropolone. Acta Crystallogr. E 2007, 63, 1063-1064. [CrossRef]

53. Kumar, V.; Singh, V.; Gupta, A.N.; Drew, M.G.B.; Singh, N. Intermolecular Tl * - H-C anagostic interactions in luminescent pyridyl functionalized thallium(I) dithiocarbamates. Dalton Trans. 2015, 44, 1716-1723. [CrossRef] [PubMed]

54. Manar, K.K.; Rajput, G.; Yadav, M.K.; Yadav, C.L.; Kumari, K.; Drew, M.G.B.; Singh, N. Potential Impact of Substituents on the Crystal Structures and Properties of Tl(I) Ferrocenyl/Picolyl-Functionalized Dithiocarbamates; Tl $\cdots H$ H-C Anagostic Interactions. ChemistrySelect 2016, 1, 5733-5742. [CrossRef]

55. Nomiya, K.; Yoshizawa, A.; Tsukagoshi, K.; Kasuga, N.C.; Hirakawa, S.; Watanabe, J. Synthesis and structural characterization of silver(I), aluminium(III) and cobalt(II) complexes with 4-isopropyltropolone (hinokitiol) showing noteworthy biological activities Action of silver(I)-oxygen bonding complexes on the antimicrobial activities. J. Inorg. Biochem. 2004, 98, 46-60. [CrossRef] [PubMed]

56. Rostkowska, H.; Lapinski, L.; Nowak, M.J.; Adamowicz, L. Normal Mode Analysis of the Vibrational Spectrum of Tropolone-a Molecule with Seven-Membered Ring. Int. J. Quantum Chem. 2002, 90, 1163-1173. [CrossRef]

57. Fernández, E.J.; Laguna, A.; López-de-Luzuriaga, J.M.; Monge, M.; Montiel, M.; Elena Olmos, M.; Pérez, J. Thallium(I) Acetylacetonate as Building Blocks of Luminescent Supramolecular Architectures. Organometallics 2004, 23, 774-782. [CrossRef]

58. European Committee on Antimicrobial Susceptibility Testing, EUCAST. Available online: https://www.eucast.org/ (accessed on 12 December 2021).

59. The United States Pharmacopeia. National Formulary; Antimicrobial effectiveness testing; Pharmacopeial Convention: Rockville, MD, USA, 2017; Volume 1.

60. Manhart, M.D. In Vitro Antimicrobial Activity of Bismuth Subsalicylate and Other Bismuth Salts. Rev. Infect. Dis. 1990, 12, S11-S15. [CrossRef] [PubMed]

61. Pitz, A.M.; Woo Park, G.; Lee, D.; Boissy, Y.L.; Vinjé, J. Antimicrobial activity of bismuth subsalicylate on Clostridium difficile, Escherichia coli O157:H7, norovirus, and other common enteric pathogens. Gut Microbes 2015, 6, 93-100. [CrossRef] 
62. Vazquez-Munoz, R.; Arellano-Jimenez, M.J.; Lopez-Ribot, J.L. Bismuth nanoparticles obtained by a facile synthesis method exhibit antimicrobial activity against Staphylococcus aureus and Candida albicans. BMC Biomed. Eng. 2020, 2, 11. [CrossRef] [PubMed]

63. Thomas, F.; Bialek, B.; Hensel, R. Medical Use of Bismuth: The Two Sides of the Coin. J. Clinic. Toxicol. $2012,3,4$.

64. Domenico, P.; Baldassarri, L.; Schoch, P.E.; Kaehler, K.; Sasatsu, M.; Cunha, B.A. Activities of Bismuth Thiols against Staphylococci and Staphylococcal Biofilms. Antimicrob. Agents Chemother. 2020, 45, 1417-1421. [CrossRef]

65. Johnston, D.H.; Shiver, D.F. Vibrational study of the trifluoromethanesulfonate anion: Unambiguous assignment of the asymmetric stretching modes. Inorg. Chem. 1993, 32, 1045-1047. [CrossRef]

66. Sheldrick, G.M. Crystal structure refinement with SHELXL. Acta Crystallogr. C 2015, 71, 3-8. [CrossRef] [PubMed]

67. Dolomanov, O.V.; Bourhis, L.J.; Gildea, R.J.; Howard, J.A.K.; Puschmann, H. OLEX2: A complete structure solution, refinement and analysis program. J. Appl. Crystallogr. 2009, 42, 339-341. [CrossRef]

68. Macrae, C.F.; Bruno, I.J.; Chisholm, J.A.; Edgington, P.R.; McCabe, P.; Pidcock, E.; Rodriguez-Monge, L.; Taylor, R.; van de Streek, J.; Wood, P.A. Mercury CSD 2.0-new features for the visualization and investigation of crystal structures. J. Appl. Crystallogr. 2008, 41, 466-470. [CrossRef]

69. ISO 20776-1:2019: Susceptibility Testing Of Infectious Agents and Evaluation of Performance of Antimicrobial Susceptibility Test Devices-Part 1: Broth Micro-Dilution Reference Method For Testing The In Vitro Activity of Antimicrobial Agents Against Rapidly Growing Aerobic Bacteria Involved In Infectious Diseases. Available online: https://www.iso.org/standard/70464.html (accessed on 1 December 2021).

70. The American Type Culture Collection (ATCC). Available online: https:/ / www.atcc.org (accessed on 1 December 2021). 